\title{
Textural and compositional evidence for a polyphase saturation of tourmaline in granitic rocks from the Třebíc Pluton (Bohemian Massif)
}

\author{
David BURIÁNEK ${ }^{1,2^{*}}$, Zdeněk DOLNÍČEK ${ }^{3}$, Milan NOVÁK ${ }^{1}$ \\ ${ }^{1}$ Department of Geological Sciences, Faculty of Science, Masaryk University, Kotlářská 2, 61137 Brno, Czech Republic; \\ david.burianek@geology.cz \\ ${ }^{2}$ Czech Geological Survey, Leitnerova 22, 60200 Brno, Czech Republic \\ ${ }^{3}$ Department of Geology, Palacký University, 17. listopadu 12, 77146 Olomouc, Czech Republic \\ * Corresponding author
}

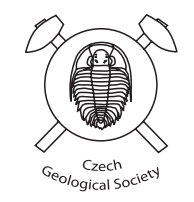

Crystallization of granite melts produced several textural types of granites and pegmatites in the Třebíc Pluton: dykes of volumetrically dominant muscovite-biotite granite (MBG) locally containing tourmaline nodules with leucocratic halos, minor oval pods to dykes of tourmaline granite and veins of tourmaline pegmatite, both enclosed in the MBG. An aplitic zone with comb textures, locally developed in MBG along the contact with surrounding durbachites, suggests high degree of undercooling. Evidence for polyphase saturation of tourmaline was observed within MBG and related granitic rocks including the following textural and compositional types of tourmaline: (i) nodules surrounded by leucocratic halos; (ii) euhedral to subhedral grains randomly distributed within tourmaline granite and tourmaline-quartz accumulations with leucocratic halos in the marginal part of granite dykes; (iii) rare columnar crystals of black tourmaline occurring locally in central parts of pegmatite; (iv) dravite-rich rims and late dravite veinlets in tourmaline grains from nodules, suggesting crystallization from hydrothermal fluids in the system open to host rocks as supported also by fluid inclusions study. The dominant substitutions in tourmaline include $\mathrm{Fe} \mathrm{Mg}_{-1},{ }^{\mathrm{X}} \mathrm{Na}^{\mathrm{Y}} \mathrm{R}^{2+\mathrm{W}} \mathrm{F}^{\mathrm{X}} \square{ }^{\mathrm{Y}} \mathrm{Al}_{-1}{ }^{\mathrm{W}} \mathrm{OH}_{-1}$ and ${ }^{\mathrm{Y}} \mathrm{R}^{2+\mathrm{W}} \mathrm{O}^{\mathrm{Y}} \mathrm{Al}_{-1}{ }^{\mathrm{W}} \mathrm{OH}_{-1}$. Based on zircon and monazite thermometry, near-solidus temperatures of $c .700-660^{\circ} \mathrm{C}$ and $680-640^{\circ} \mathrm{C}$ were estimated for the central part of the MBG dykes and the volatile-rich tourmaline granite, respectively.

Keywords: tourmaline, chemical composition, granite, pegmatite, magma evolution, fluid inclusions Received: 14 March, 2016; accepted: 15 December, 2016; handling editor: J. Žák

\section{Introduction}

Strongly peraluminous granites generated by partial melting of metasedimentary rocks typically contain elevated contents of boron (e.g. Greenfield et al. 1996, 1998; Trumbull et al. 2008). Tourmalines occur in peraluminous granite-pegmatite systems as disseminated and nodular in granites, or a wide spectrum of textural and compositional types in granitic pegmatites and associated quartz veins (e.g. Sinclair and Richardson 1992; Rozendaal and Bruwer 1995; London et al. 1996; Pesquera et al. 2013). The progressive cooling and fractional crystallization of a B-bearing granitic melt may produce two conjugate melts, a B- $\mathrm{H}_{2} \mathrm{O}$-poor peraluminous melt, and a B-rich melt (e.g. Thomas et al. 2003; Perugini and Poli 2007), or an immiscible, B-rich aqueous fluid phase (e.g. Sinclair and Richardson 1992; Rozendaal and Bruwer 1995). Such immiscible volatile-rich melts and/or hydrous fluids can be separated during late stages of peraluminous melt evolution to produce various tourmaline-bearing rocks (Veksler et al. 2002; Thomas et al. 2003; Bačík et al. 2013).

Tourmaline from granitic rocks has been routinely examined in the Bohemian Massif (e.g., Němec 1975; Holub et al. 1981; Povondra 1981; Povondra et al. 1998; Buriánek and Novák, 2004, 2007). Detailed studies of distinct textural, compositional and paragenetic types of this mineral from texturally variable dykes of nodular tourmaline granites in the Třebíč Pluton (Buriánek and Novák 2004, 2007) provide an insight on the mechanism controlling the behavior of B during crystallization of granite melt. The studied granitic rocks are excellent examples of tourmaline textures variability and document several stages of granite evolution, from magmatic to hydrothermal.

\section{Geological setting}

The Moldanubian Zone, the highly metamorphosed core of the Bohemian Massif, represents a crustal (and upper mantle) tectonic collage assembled during the Variscan Orogeny and modified by several events of superimposed deformations and high- to low-grade metamorphism. The following two main units were defined (e.g. Schulmann et al. 2009 and references therein).

The mid-crustal Drosendorf Unit mainly consists of sillimanite-biotite-cordierite migmatites and para- 
$15^{\circ} 45^{\prime} \mathrm{E}$

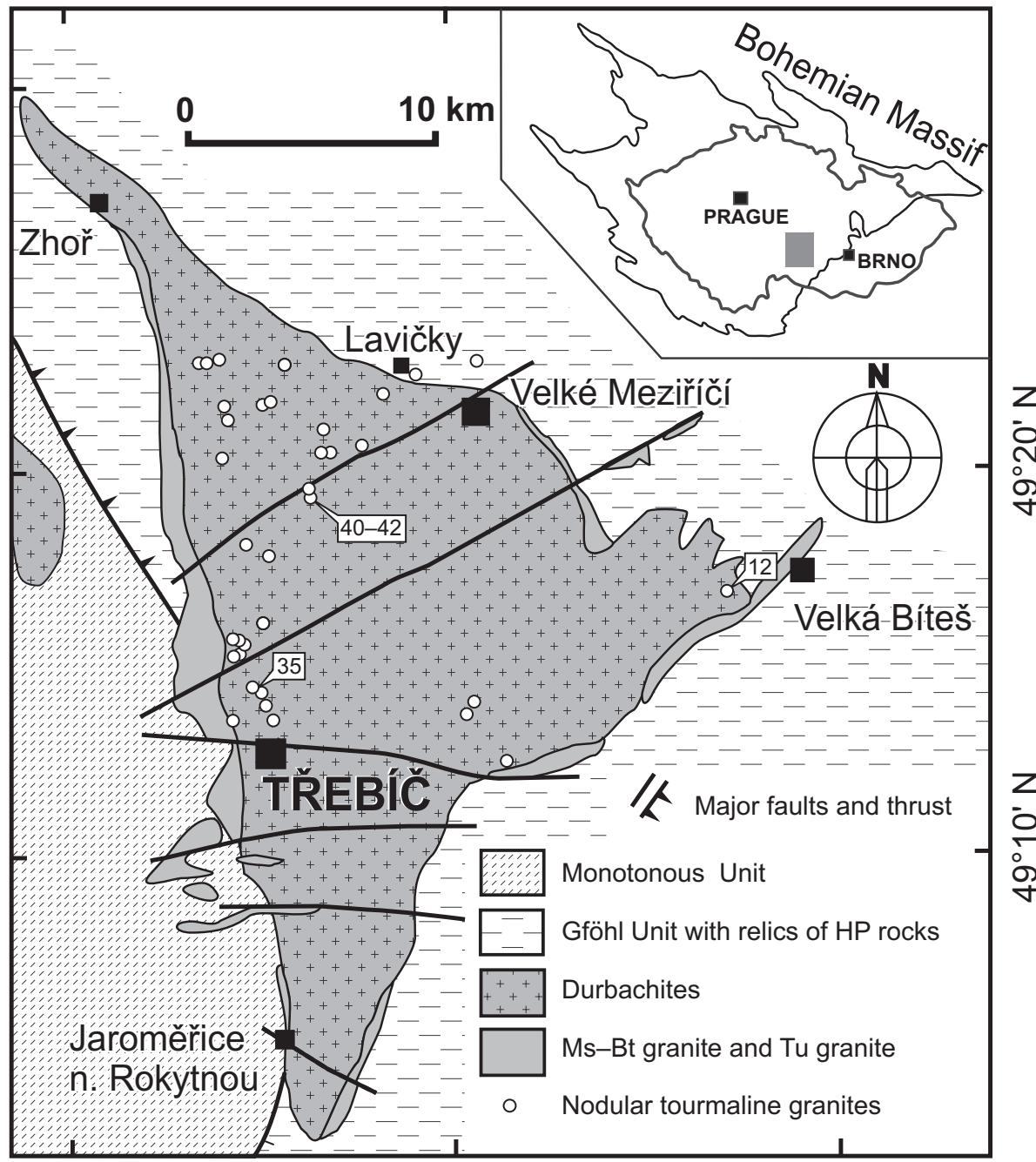

$16^{\circ} 00^{\prime} \mathrm{E}$

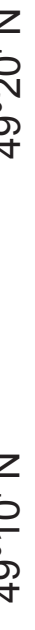

Fig. 1 Geological sketch map of the Třebíč Pluton with the sample locations (modified after Bubeníček 1968). Grey rectangle in the inset map shows location of the area of interest within the Czech Republic and Bohemian Massif. Detailed informations about the samples are shown in Tab. 1. gneisses with variable intercalations of amphibolites, marbles, calc-silicate rocks, graphitic gneisses, quartzites and orthogneisses. The lower-crustal/upper-mantle Gföhl Unit is dominated by felsic orthogneisses to migmatites and migmatized biotite paragneisses. They are typically associated with amphibolites, HP felsic granulites and minor pyroxene granulites accompanied by variably sized bodies of spinel/pyrope peridotites and eclogites.

The Variscan tectonometamorphic history of the Moldanubian Zone was marked by an extensive igneous activity from Late Devonian to Permian (see Holub et al. 1995; Finger et al. 1997, 2007; Breiter 2010; Žák et al. 2014). This magmatism included (ultra-) potassic, magnesium-rich quartz syenitic to melagranitic plutons (durbachites), which were emplaced shortly after the exhumation of the high-grade Gföhl Unit (Holub et al. 1997; Janoušek and Holub 2007; Leichmann et al. 2017), and accompanied with common peraluminous tourmaline-bearing granites (Buriánek and Novák 2007).
The Třebíč Pluton (Fig. 1) represents one of these ultrapotassic bodies. It is composed of amphibole-biotite (quartz) melasyenites to melagranites (durbachites), which were emplaced into medium- to high-grade metamorphic rocks of the Gföhl Unit at upper-crustal levels ( 2-4 kbar) (Novák and Houzar 1996; Houzar and Novák 2006; Leichmann et al. 2017) at $341.6 \pm 2.8 \mathrm{Ma}$ (U-Pb SHRIMP on zircon: Kusiak et al. 2010) or $334.8 \pm 3.2$ Ma (conventional U-Pb on zircon: Kotková et al. 2010). The bulk-rock compositions in the Třebíc Pluton are metaluminous $(\mathrm{A} / \mathrm{CNK}=0.85-0.93)$ with high concentrations of $\mathrm{K}_{2} \mathrm{O}$ (5.2-6.5 wt. \%), $\mathrm{MgO}$ (3.3-10.4 wt. \%) and $\mathrm{P}_{2} \mathrm{O}_{5}(0.47-0.98$ wt. \%) as well as high $\mathrm{K} / \mathrm{Rb}$ ratios (133-171). The high $\mathrm{Cr}$, Ni and mg\#, along with striking enrichments in U, Th, LREE (Light Rare Earth Elements) and LILE (Large-Ion Lithophile Elements), depletion in HFSE (High Field Strength Elements) and crustal-like $\mathrm{Sr}-\mathrm{Nd}$ isotopic compositions, suggest an origin from anomalously enriched mantle domains (Holub 1997; Wenzel et al. 1997) perhaps contaminated by the deeply 
subducted mature crust (Janoušek and Holub 2007; Lexa et al. 2011).

Small intrusive bodies of subaluminous to slightly peraluminous leucogranites commonly with quartz-tourmaline nodules are spatially related to the durbachitic plutons (Třebíč, Čertovo břemeno and Mehelník intrusions; Němec 1975; Buriánek and Novák 2007) intruding durbachites and host migmatized biotite-sillimanite paragneiss (Novák et al. 1997; Buriánek and Novák 2003, 2004, 2007). The granite that crops out near the village of Lavičky is a typical example of such a peraluminous body (Novák et al. 1997; Buriánek and Novák 2003, 2004, 2007; Jiang et al. 2003; Marschall and Ludwig 2006). It is cut by a steeply-dipping pegmatite dyke (Pl $+\mathrm{Qtz}+\mathrm{Kfs}+\mathrm{Mu}+\mathrm{Bt}$ ), up to $30 \mathrm{~cm}$ thick, with simply zoned internal structure and minor tourmaline (Al-rich schorl) with accessory fluorapatite and allanite (Novák et al. 1997).

Numerous intragranitic pegmatites $(\mathrm{Pl}+\mathrm{Qtz}+\mathrm{Kfs}$ $+\mathrm{Bt})$ in the Třebíč Pluton contain minor to accessory actinolitic amphibole, allanite-(Ce), ilmenite, titanite, and black tourmaline (dravite to schorl) along with a wide spectrum of accessory minerals, i.e. aeschynite- and euxenite-group minerals, beryl, niobian rutile, titanite and zircon in the most evolved dykes (Škoda et al. 2006; Škoda and Novák 2007; Novák and Filip 2010; Novák et al. 2011; Čopjaková et al. 2013, 2015; Zachař and Novák 2013). The pegmatites form small nests to dykes, up to $2 \mathrm{~m}$ thick, commonly with transitional contacts to the host durbachite. They evidently differ from the dykes of peraluminous nodular granites by the absence of primary muscovite, high $\mathrm{X}_{\mathrm{Mg}}$ in biotite, low contents of $\mathrm{P}$ in feldspars and tourmaline composition $(\mathrm{Ca}$, Ti-rich Al-poor dravite-schorl; Škoda et al. 2006; Novák et al. 2011). The $\delta^{11} \mathrm{~B}$ signature of tourmalines from these intragranitic pegmatites $\left(\delta^{11} \mathrm{~B}=-13.5\right.$ to $\left.-14.6 \%\right)$, from the pegmatite cutting the Lavičky granite $\left(\delta^{11} \mathrm{~B}=-11.9 \%\right)$ and from tourmaline nodules in the Lavičky granite $\left(\delta^{11} \mathrm{~B}=-10.8 \%\right.$; Marschall and Ludwig 2006; Míková et al. 2010) are typical of granitic pegmatites and granites (Marschall and Jiang 2011).

\section{Analytical methods}

Chemical analyses of minerals were obtained using a Cameca SX-100 electron microprobe at the Joint Laboratory of the Department of Geological Sciences, Faculty of Science, Masaryk University in Brno and the Czech Geological Survey, Brno. The measurements were carried out in a wave-dispersion mode under the following conditions: acceleration voltage of $15 \mathrm{kV}$, beam diameter of $5 \mu \mathrm{m}$ and probe current of $30 \mathrm{nA}$. The integration time was $20 \mathrm{~s}$ and the standards employed $\left(\mathrm{K}_{\alpha}\right.$ lines) were: augite $(\mathrm{Si}, \mathrm{Mg})$, orthoclase $(\mathrm{K})$, jadeite $(\mathrm{Na})$, chromite $(\mathrm{Cr})$, almandine $(\mathrm{Al})$, andradite $(\mathrm{Fe}, \mathrm{Ca})$, rhodonite $(\mathrm{Mn})$ and $\mathrm{TiO}_{2}(\mathrm{Ti})$. Data were reduced on-line using the PAP routine procedure (Pouchou and Pichoir 1985). Crystalchemical formulae of tourmaline were calculated based on the general formula $X Y_{3} Z_{6} T_{6} O_{18}\left(B O_{3}\right)_{3} V_{3} W$, where $X=\mathrm{Na}, \mathrm{Ca}$, vacancies; $Y=\mathrm{Fe}, \mathrm{Mg}, \mathrm{Mn}, \mathrm{Ti}, \mathrm{Al} ; Z=\mathrm{Al}$; $T=\mathrm{Si}, \mathrm{Al} ; B=\mathrm{B} ; V+W=\mathrm{OH}+\mathrm{F}=4$, normalized on $31(\mathrm{O}, \mathrm{OH}, \mathrm{F})$ apfu, assuming the $Z$-site is fully occupied by $\mathrm{Al}, \mathrm{Fe}_{\text {tot }}$ as $\mathrm{FeO}$ and no Li (Henry et al. 2011). Mineral abbreviations given in text, figures and tables have been taken from Whitney and Evans (2010).

About 3-4 kg samples (Tab. 1) were crushed (by steel jaw crusher) and homogenized in an agate planetary ball mill for the whole-rock chemical analyses. Major and trace elements were determined at Acme Analytical Laboratories, Ltd., Vancouver, Canada. Major oxides were analyzed by the ICP-OES method. Loss on ignition (LOI) was calculated from the weight difference after the ignition at $1000^{\circ} \mathrm{C}$. The rare earth and other trace elements were analysed by ICP-MS following $\mathrm{LiBO}_{2}$ fusion (analytic code: A4B4 - major oxides, $\mathrm{Ba}, \mathrm{Be}, \mathrm{Co}$, $\mathrm{Cr}, \mathrm{Cs}, \mathrm{Ga}, \mathrm{Hf}, \mathrm{Nb}, \mathrm{Ni}, \mathrm{Rb}, \mathrm{Sc}, \mathrm{Sr}, \mathrm{Ta}, \mathrm{Th}, \mathrm{U}, \mathrm{V}, \mathrm{W}, \mathrm{Y}$, $\mathrm{Zr}$, REE; 1DX - Ag, As, Au, Bi, Cd, Cu, Hg, Mo, Ni, Pb, $\mathrm{Sb}, \mathrm{Se}, \mathrm{Tl}, \mathrm{Zn}$; 2ALeco - Ctot, Stot; for analytical details, reproducibility, and detection limits see http://acmelab. com). Geochemical data were handled and plotted using the GCDkit software package (Janoušek et al. 2006).

Oxygen isotope measurements were performed using a Finnigan MAT 251 mass spectrometer at the Activation Laboratories in Ancaster, Canada. Silicates were reacted with $\mathrm{BrF}_{5}$ at $\sim 650^{\circ} \mathrm{C}$ in nickel bombs following the procedures described in Clayton and Mayeda (1963). Oxygen released in this way was subsequently converted to $\mathrm{CO}_{2}$ using a hot $\mathrm{C}$ rod. All $\delta^{18} \mathrm{O}$ values are expressed relative to the standard mean ocean water (SMOW); external reproducibility is $\pm 0.19 \%$ o $(1 \sigma)$.

Fluid inclusions (FI) have been petrographically and microthermometrically studied in standard doubly polished plates. Individual genetic types of FI were recognized according to the criteria of Roedder (1984) and Shepherd et al. (1985). Microthermometric parameters were obtained using a Linkam THMSG 600 heatingfreezing stage mounted on an Olympus BX-51 microscope (Department of Geology, Palacký University in Olomouc). The stage was calibrated using inorganic standards and fluid inclusions with known phase transition temperatures. The following parameters were measured: initial melting temperature (Te), melting temperature of the last ice (Tm-ice), melting temperature of clathrate (Tm-cla) and temperature of total homogenization (Th-tot). Interpretation of the microthermometric data (composition, densities and isochores) was performed using the FLUIDS and FLINCOR software packages 
Tab. 1 Location and parageneses of studied samples (WGS84 geographic coordinate system)

\begin{tabular}{|c|c|c|c|}
\hline locality & sample & rock type & mineral assemblage \\
\hline Budíkovice & GB35/G2 & MBG & $\mathrm{Qtz}+\mathrm{Pl}+\mathrm{Kfs}+\mathrm{Bt}+\mathrm{Ms}+\mathrm{Ap}+\mathrm{Mnz}+\mathrm{Zrn}$ \\
\hline N 4914'48.7" & GB35/N & $\mathrm{TN}$ & $\mathrm{Qtz}+\mathrm{Tu}+\mathrm{Pl}+\mathrm{Kfs}+\mathrm{Ms}+\mathrm{Ap}$ \\
\hline \multirow[t]{5}{*}{ E $15^{\circ} 52^{\prime} 12.2^{\prime \prime}$} & GB35/L & $\mathrm{LH}$ & $\mathrm{Qtz}+\mathrm{Pl}+\mathrm{Kfs} \pm \mathrm{Ms}+\mathrm{Ap}$ \\
\hline & GB35/G & $\mathrm{TP}$ & $\mathrm{Qtz}+\mathrm{Pl}+\mathrm{Kfs}+\mathrm{Bt}+\mathrm{Ms}+\mathrm{Ap}+\mathrm{Mnz}+\mathrm{Zrn}+\mathrm{Ilm}+\mathrm{Rt} \pm \mathrm{Tu}$ \\
\hline & GB35/I & MBG & $\mathrm{Qtz}+\mathrm{Pl}+\mathrm{Kfs}+\mathrm{Bt}+\mathrm{Ms}+\mathrm{Ap}+\mathrm{Mnz}+\mathrm{Zrn}$ \\
\hline & GB35/T2 & TG & $\mathrm{Qtz}+\mathrm{Tu}+\mathrm{Pl}+\mathrm{Kfs}+\mathrm{Ms}+\mathrm{Ap}$ \\
\hline & GB35/L6 & $\mathrm{LH}$ & $\mathrm{Qtz}+\mathrm{Pl}+\mathrm{Kfs} \pm \mathrm{Ms}+\mathrm{Ap}$ \\
\hline Horní Radslavice & $\mathrm{GB} 40 / \mathrm{G}$ & MBG & $\mathrm{Qtz}+\mathrm{Pl}+\mathrm{Kfs}+\mathrm{Bt}+\mathrm{Ms}+\mathrm{Cdr}+\mathrm{Ap}+\mathrm{Mnz}+\mathrm{Zrn}+\mathrm{Ilm}$ \\
\hline $\mathrm{N} 49^{\circ} 20^{\prime} 30.0^{\prime \prime}$ & $\mathrm{GB} 40 / \mathrm{N}$ & $\mathrm{TN}$ & $\mathrm{Qtz}+\mathrm{Tu}+\mathrm{Pl}+\mathrm{Kfs}+\mathrm{Ap} \pm \mathrm{Ilm}$ \\
\hline E $15^{\circ} 54^{\prime} 07.0^{\prime \prime}$ & GB40/L & $\mathrm{LH}$ & $\mathrm{Qtz}+\mathrm{Pl}+\mathrm{Kfs} \pm \mathrm{Ms}+\mathrm{Ap}$ \\
\hline Svatoslav & $\mathrm{GB} 41 / \mathrm{G}$ & MBG & $\mathrm{Qtz}+\mathrm{Pl}+\mathrm{Kfs}+\mathrm{Bt}+\mathrm{Ms}+\mathrm{Ap}+\mathrm{Mnz}+\mathrm{Zrn}+\mathrm{Ilm}$ \\
\hline $\mathrm{N} 49^{\circ} 20^{\prime} 26.5^{\prime \prime}$ & GB41/N & $\mathrm{TN}$ & $\mathrm{Qtz}+\mathrm{Tu}+\mathrm{Pl}+\mathrm{Kfs}+\mathrm{Ap}$ \\
\hline \multirow[t]{2}{*}{ E $15^{\circ} 51^{\prime} 27.8^{\prime \prime}$} & GB41/L & $\mathrm{LH}$ & $\mathrm{Qtz}+\mathrm{Pl}+\mathrm{Kfs} \pm \mathrm{Ms}+\mathrm{Ap}$ \\
\hline & GB41/P & $\mathrm{TP}$ & $\mathrm{Qtz}+\mathrm{Pl}+\mathrm{Kfs}+\mathrm{Tu} \pm \mathrm{Ms}+\mathrm{Ap}$ \\
\hline Svatoslav & $\mathrm{GB} 42 / \mathrm{O}$ & MBG & $\mathrm{Qtz}+\mathrm{Pl}+\mathrm{Kfs}+\mathrm{Bt}+\mathrm{Ms}+\mathrm{And}+\mathrm{Ap}+\mathrm{Mnz}+\mathrm{Zrn}$ \\
\hline N 49²0'22.7" & GB42/N & $\mathrm{TN}$ & $\mathrm{Qtz}+\mathrm{Pl}+\mathrm{Kfs}+\mathrm{Tu}+\mathrm{Ap}$ \\
\hline \multirow[t]{3}{*}{ E $15^{\circ} 52^{\prime} 25.4^{\prime \prime}$} & GB42/L & $\mathrm{LH}$ & $\mathrm{Qtz}+\mathrm{Pl}+\mathrm{Kfs} \pm \mathrm{Ms}+\mathrm{Ap}$ \\
\hline & GB42/B & TG & $\mathrm{Qtz}+\mathrm{Pl}+\mathrm{Tu}+\mathrm{Kfs}+\mathrm{Bt}+\mathrm{Ms}$ \\
\hline & $\mathrm{GB} 42 / \mathrm{P}$ & $\mathrm{TP}$ & $\mathrm{Qtz}+\mathrm{Pl}+\mathrm{Kfs}+\mathrm{Tu} \pm \mathrm{Ms}+\mathrm{Ap}$ \\
\hline Březka & GB12/G & MBG & $\mathrm{Qtz}+\mathrm{Pl}+\mathrm{Kfs}+\mathrm{Bt}+\mathrm{Ms}+\mathrm{Ap}+\mathrm{Mnz}+\mathrm{Zrn}$ \\
\hline N 49॰17'00.2" & $\mathrm{GB} 12 / \mathrm{N}$ & $\mathrm{TN}$ & $\mathrm{Qtz}+\mathrm{Tu}+\mathrm{Pl}+\mathrm{Kfs}+\mathrm{Ap}$ \\
\hline E $16^{\circ} 09^{\prime} 59.6^{\prime \prime}$ & $\mathrm{GB} 12 / \mathrm{L}$ & $\mathrm{LH}$ & $\mathrm{Qtz}+\mathrm{Pl}+\mathrm{Kfs} \pm \mathrm{Ms}+\mathrm{Ap}$ \\
\hline
\end{tabular}

Rock types: muscovite-biotite granites (MBG), tourmaline granites (TG), leucocratic halos (LH), tourmaline nodules (TN), tourmaline pegmatites (TP)

(Brown 1989; Bakker 2003) with calibrations by Zhang and Frantz (1987) and Duan et al. (1992) for $\mathrm{H}_{2} \mathrm{O}-\mathrm{CH}_{4}-$ $\mathrm{NaCl}$ and $\mathrm{H}_{2} \mathrm{O}-\mathrm{NaCl}$ fluids, respectively. The Raman analysis of vapor phase in fluid inclusions was done by $\mathrm{V}$. Mašek at the Institute of the Molecular and Translational Medicine, Olomouc (Czech Republic) using the WITec Confocal Raman Imaging Microscope System alpha300 $\mathrm{R}+$ with excitation wavelength of $532 \mathrm{~nm}$, laser power of $25 \mathrm{~mW}, 50 \times / \mathrm{NA} 0.8$ objective, and spectra acquisition time of $60 \mathrm{~s}$.

\section{Results}

\subsection{Geological setting, internal structure of granite dykes, and petrography of the individual rock types}

Dykes of peraluminous granites including common nodular tourmaline granites (Buriánek and Novák 2004, 2007) crosscut the Třebíć Pluton and are predominantly oriented NE-SW to NNE-SWW (Fig. 1, Tab. 1). These dykes, $\sim 1-6 \mathrm{~m}$ thick and up to $15 \mathrm{~m}$ long, have heterogeneous internal structures and typically sharp contacts to their host durbachites. Only the Lavičky granite body cutting durbachite and surrounding migmatized gneisses is larger, up to $\sim 50$ thick (Novák et al. 1997). Mediumgrained, muscovite-biotite granite (Fig. 2a-b) is the most abundant rock type and commonly forms about 90 vol. \% of the individual granite bodies. Scarcely, biotite-rich restitic enclaves, up to several $\mathrm{cm}$ across, are present close to the contacts. Based on the texture, shape, spatial relations and mineral assemblages, the following rock types were distinguished (Fig. 2a-h):

Muscovite-biotite granite (MBG) (Qtz 23-36, Pl 24-40, perthitic Kfs 23-44, chloritized Bt 4-11, secondary Ms $0-7$; all in vol. \%) with accessory muscovitized andalusite and micaceous pseudomorphs after cordierite contains anhedral to subhedral K-feldspar $\left(\mathrm{Ab}_{03-12}\right)$ and subhedral plagioclase (Fig. 3a) with normal oscillatory zoning $\left(\mathrm{Ab}_{82-96}\right)$. Granophyric and aplitic textures and/ or wedge-shaped $\mathrm{K}$-feldspar are often present in up to several $\mathrm{dm}$ thick outer zone of the dyke.

Tourmaline-rich nodules (TN) (Qtz 19-57, Tur 22-48, Pl 5-26, perthitic Kfs 1-20; all in vol. \%) are circular (Fig. 2a), oval (Fig. 2b-c), ring-shaped (Fig.

Fig. 2 Field photographs: a - tourmaline nodules (TN) and dyke of the tourmaline granite (TG) in the muscovite-biotite granite (MBG); leucocratic halo $(\mathrm{LH})$ surrounds tourmaline nodule and tourmaline granite dykes (Svatoslav; GB42); b - tourmaline granite dykes crosscutting the muscovite-biotite granite (Budíkovice; GB35); c - tourmaline nodules from Svatoslav (GB41); d - accumulation of several tourmaline nodules surrounded by leucocratic halos which partially replaced aplitic zone with comb layering in the muscovite-biotite granite (Svatoslav; GB42); e - ring-shaped tourmaline nodule enclosing muscovite-biotite granite; leucocratic halo surrounds only the external part of this ring (Horní Radslavice; GB40); $\mathbf{f}$ - irregular shape of tourmaline nodule dominated by tourmaline in the central part (Svatoslav; GB41); $\mathbf{g}$ - pegmatite dykes with tourmaline accumulations (Svatoslav; GB41); $\mathbf{h}$ - pegmatite with comb-structured intergrowth of quartz, feldspar and needle-like tourmaline (Svatoslav; GB42). 

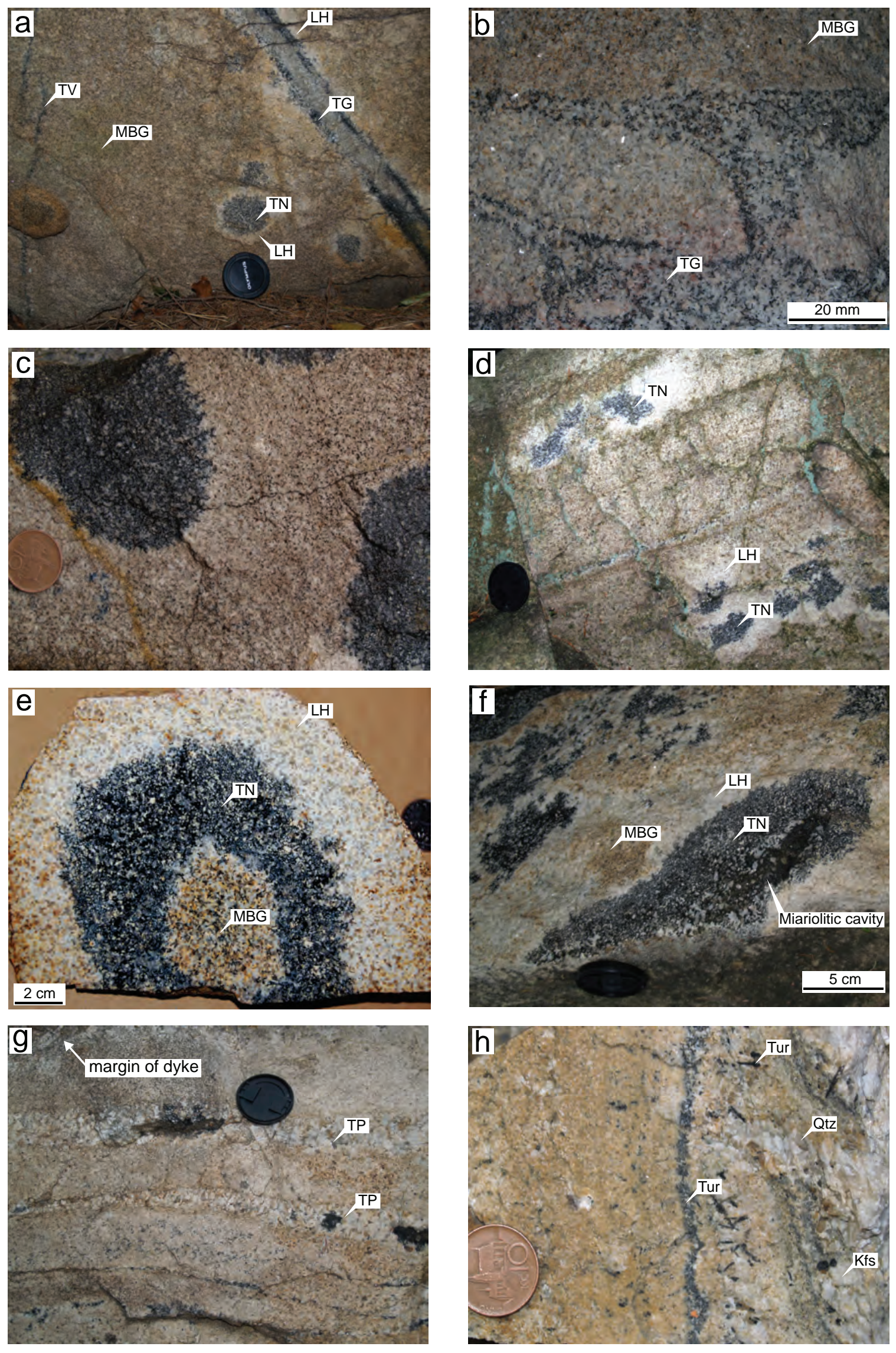

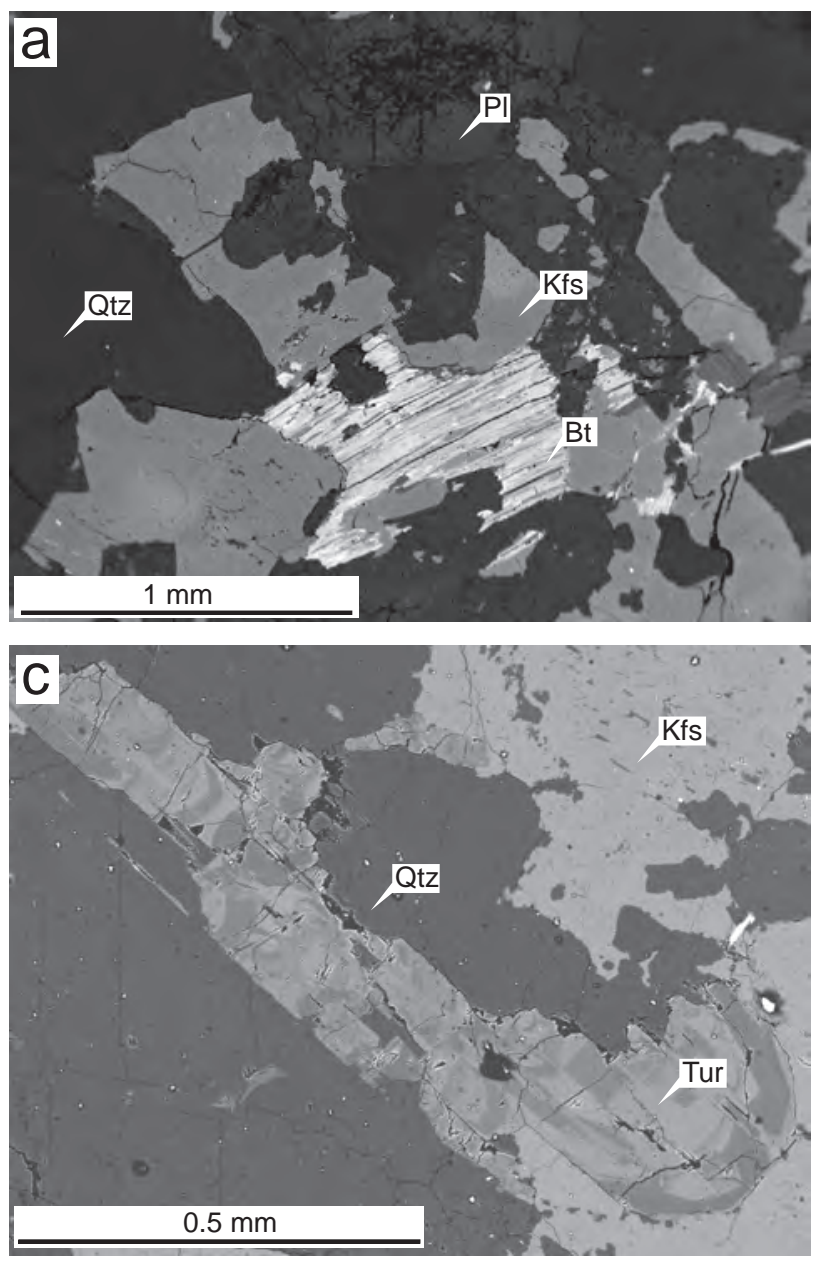
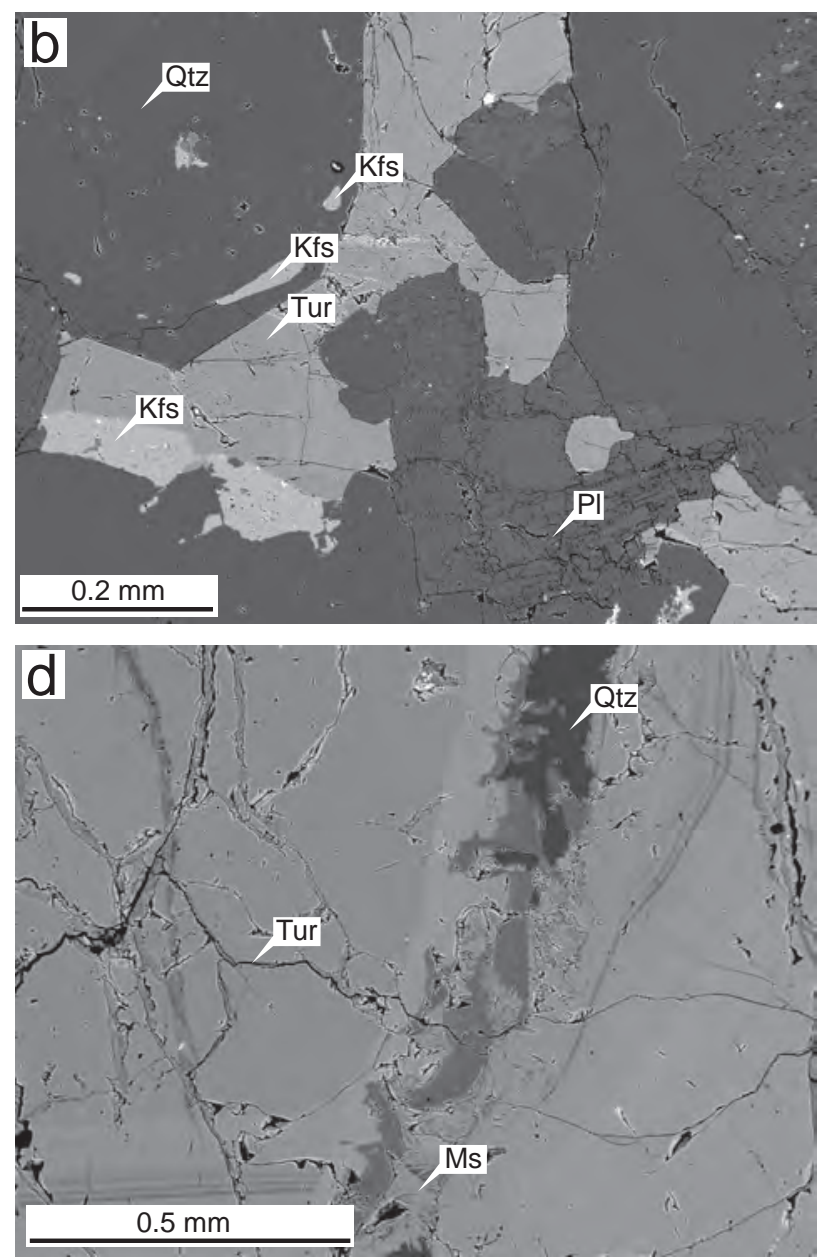

Fig. 3 Representative backscattered-electron (BSE) images: a - chloritization of biotite and sericitization of plagioclase from muscovite-biotite granite (GB42); b - tourmaline and quartz partially replacing K-feldspar in the central part of a tourmaline nodule (GB41); $\mathbf{c}$ - zoning of tourmaline in the tourmaline granite (GB35); $\mathbf{d}$ - quartz-tourmaline vein with muscovite crosscutting a tourmaline grain in the pegmatite (GB42).

2d), or irregular, 2 to $20 \mathrm{~cm}$ in diameter. They are locally associated with quartz-tourmaline veins (QTV) and veins with texture and modal composition resembling the tourmaline-rich nodules (TNV), only up to several $\mathrm{cm}$ thick (Fig. 2a). Nodules are randomly distributed or concentrated in several meters wide zones within MBG (Novák et al. 1997; Buriánek and Novák 2004) and locally contain tourmaline crystals, $1-3 \mathrm{~mm}$ in size, propagating into the leucocratic halos of the nodules (Fig. 2c). Very rare miarolitic cavities, up to $5 \mathrm{~mm}$ thick, were found in centers of some nodules (Fig. 2f). Anhedral to subhedral tourmaline (Fig. 2c-d), commonly $0.1-2 \mathrm{~mm}$ in size, is typically interstitial between grains of quartz and feldspars and commonly replaces altered plagioclase $\left(\mathrm{Ab}_{82-100}\right)$ or albite perthites in K-feldspar, whereas $\mathrm{K}$ feldspar $\left(\mathrm{Ab}_{2-14}\right)$ is usually stable (Fig. $\left.3 b\right)$. Tourmaline grains are locally crosscut by quartz-tourmaline veins, up to $0.5 \mathrm{~mm}$ thick. Anhedral to euhedral fluorapatite, forming also rare inclusions in $\mathrm{K}$-feldspar, predominates over minor xenotime-(Y) and monazite-(Ce).
Leucocratic halos (LH), 0.5 to $3.0 \mathrm{~cm}$ thick, rim each nodule as well as tourmaline veins (see also Novák et al. 1997; Buriánek and Novák 2004) and their thickness is related to the size (thickness) of the nodule (vein). The halos (Fig. 2a, d, f) consist of quartz (35-40 vol. \%), K-feldspar (29-32 vol. \%), plagioclase (28-32 vol. \%) and muscovite (0-4 vol. \%). They show similar textural features as the host MBG, including the nature of zoning of strongly sericitized plagioclase.

Tourmaline-bearing granite (Qtz 26-31, Kfs 27-30, Pl 29-32, Ms 0-4,Tur 16-22; all in vol. \%) forms thin irregular accumulations or veins, up to $5 \mathrm{~cm}$ thick, within the MBG (Fig. 2a-b). It occasionally encloses enclaves of MBG, several dm across, that are slightly more leucocratic than the typical MBG (Fig. 2b). Euhedral to subhedral grains of tourmaline (Fig. 3c), 1 to $5 \mathrm{~mm}$ in size, are randomly distributed (Fig. 2b). However, locally small tourmaline-quartz accumulations with leucocratic halo are present in the marginal part of the tourmaline-bearing granite dykes (Fig. 2a). Zircon, monazite, xenotime and 
fluorapatite are common accessory minerals. Chemical composition of subhedral oscillatory zoned plagioclase $\left(\mathrm{Ab}_{89-99}\right)$ and anhedral $\mathrm{K}$-feldspar $\left(\mathrm{Ab}_{3-12}\right)$ are very similar to those in the MBG host.

Pegmatites with tourmaline form rare dykes, up to $35 \mathrm{~cm}$ thick, predominantly located in the external part of the MBG bodies. They are usually built of an internal coarse-grained granitic unit with biotite and andalusite or tourmaline. Layered or comb textures are occasionally developed along the contact with the surrounding granites. Only in the innermost unit columnar crystals of black tourmaline, up to $2 \mathrm{~cm}$ long (Fig. $2 \mathrm{~g}$ ), locally appear. Needle-like tourmaline (Fig. 2h), wedge-shaped K-feldspar, quartz and plagioclase alternate in several $\mathrm{mm}$ to $\mathrm{cm}$ thick layers (Fig. 2h). Elongated grains of K-feldspar $\left(\mathrm{Ab}_{9-14}\right)$ and plagioclase $\left(\mathrm{Ab}_{88-97}\right), 1-4 \mathrm{~mm}$ long, are frequently oriented perpendicular to the contact with the host MBG. Tourmaline partly replaces andalusite or albite perthites in the K-feldspar. Columnar crystals of tourmaline are locally crosscut by quartz-tourmaline veins up to $0.8 \mathrm{~mm}$ thick (Fig. 3d). Late quartz veins with fibrous tourmaline (dravite) described by Novák et al. (1997) from the Lavičky granite were not studied in detail.

\subsection{Whole-rock chemistry and oxygen isotope composition}

Muscovite-biotite granites (MBG) and leucocratic halos are subaluminous to peraluminous rocks $(\mathrm{A} / \mathrm{CNK}=1.04$ to 1.20$)$ with $\mathrm{SiO}_{2}$ contents of $73-76$ wt. \% (Tab. 2). Relatively low contents of F (10-410 ppm) and B $(<10-454$ ppm) are typical (Fig. 4a; Tab. 2). The leucocratic halos have higher $\mathrm{K}_{2} \mathrm{O}$ and lower $\mathrm{TiO}_{2}$ contents than the host MBG (Fig. $4 \mathrm{~b}-\mathrm{c})$. Both tourmaline-bearing granites and nodules contain significant amounts of B, F, $\mathrm{TiO}_{2}, \mathrm{Al}_{2} \mathrm{O}_{3}, \mathrm{Fe}_{2} \mathrm{O}_{3}$ (total) and $\mathrm{MgO}$ (Tab. 2). Fluorine contents (400-1480 ppm) in tourmaline-bearing granite and tourmaline nodules correlate positively with B (Fig. 4a).

Muscovite-biotite granites are enriched in LILE when compared to the bulk continental crust (Taylor and McLennan 1995) except for some samples with lower $\mathrm{Ba}$ (138-602 ppm, Fig 4d). The $\mathrm{CaO} / \mathrm{Na}_{2} \mathrm{O}(0.11-0.23), \mathrm{Rb} / \mathrm{Sr}$ (1-8), and $\mathrm{Rb} / \mathrm{Ba}(0.4-2.5)$ ratios (Tabs 2-3) correspond to melts derived by partial melting

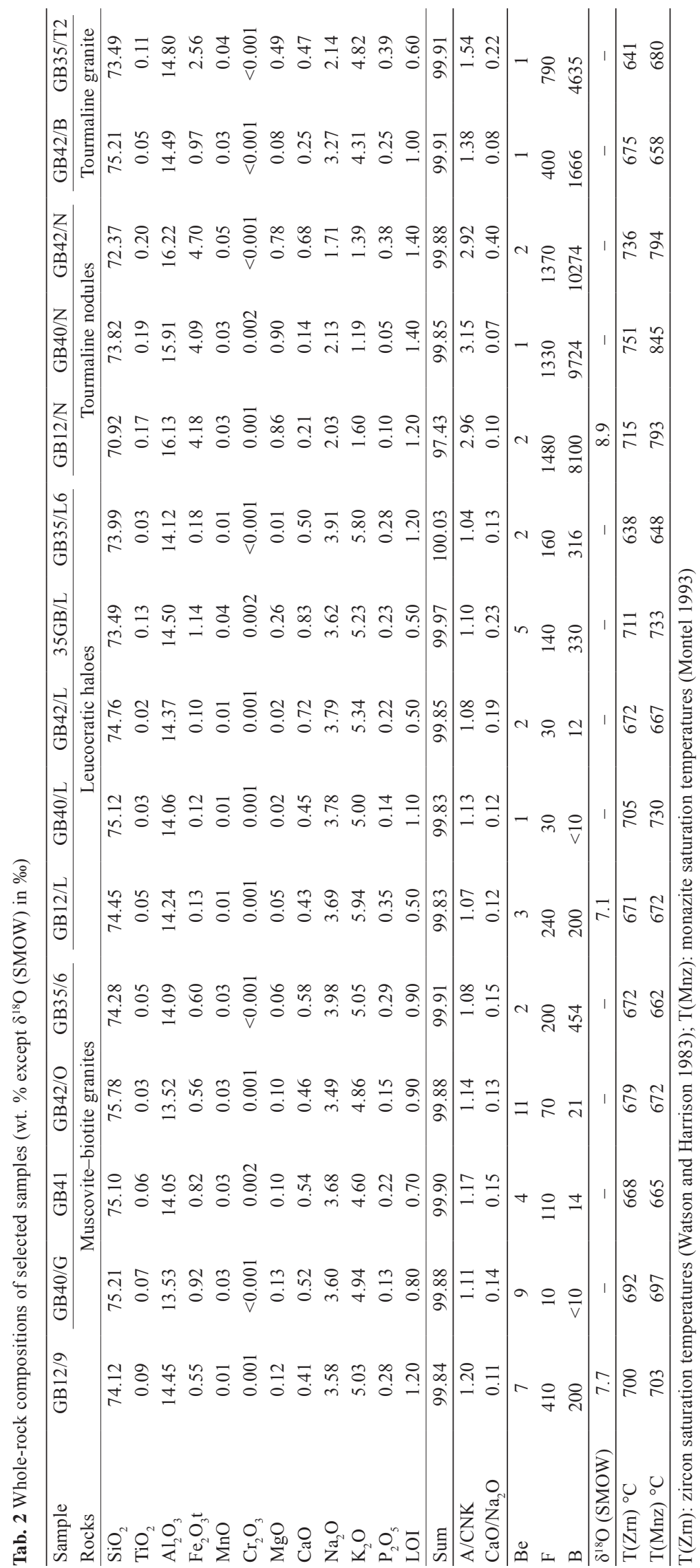



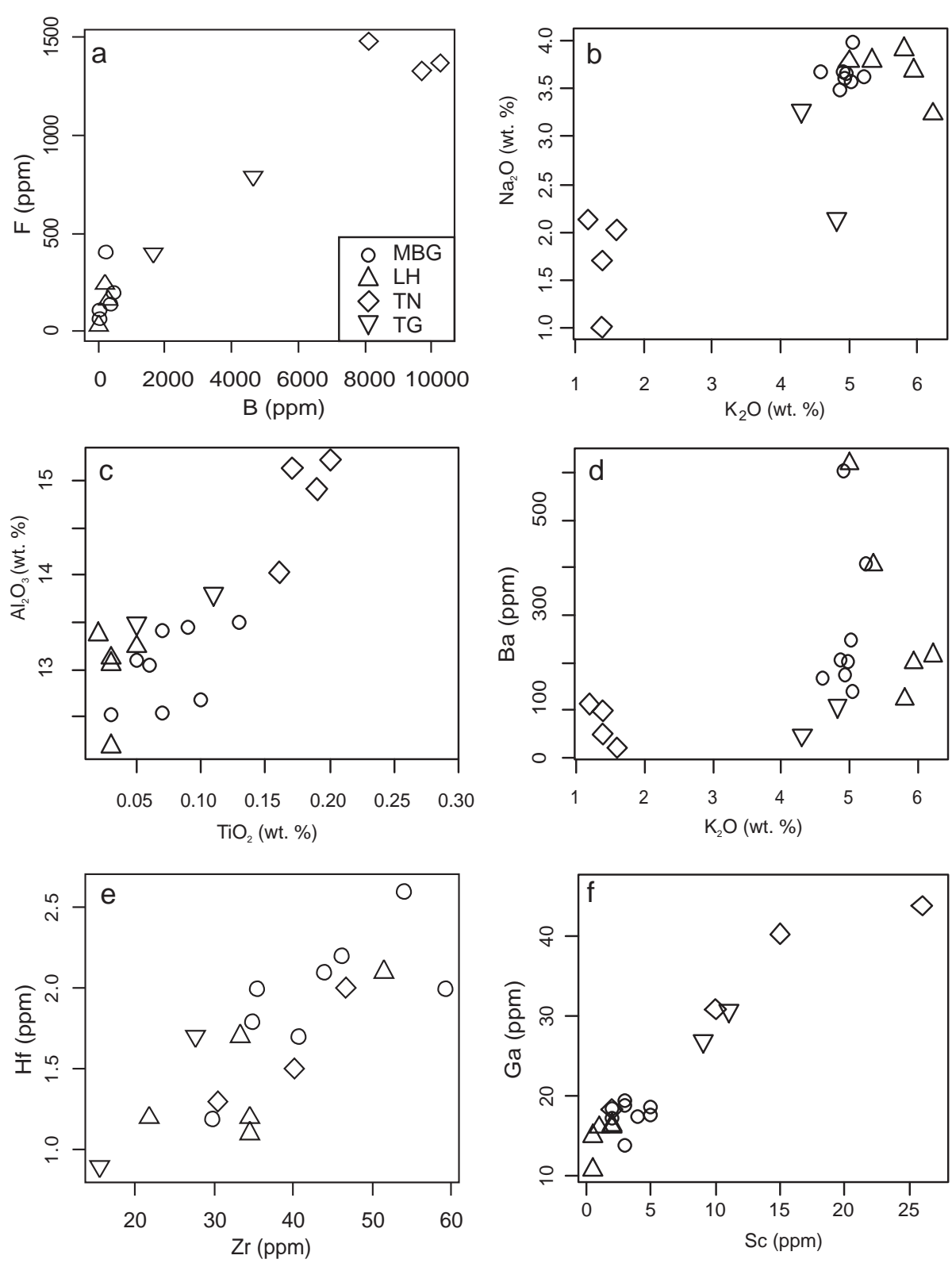

Fig. 4 Selected major- and trace-element variation diagrams for the muscovite-biotite granite, leucocratic halos, tourmaline nodules and tourmaline granites: $\mathbf{a}-\mathrm{B}$ vs. $\mathrm{F} ; \mathbf{b}-\mathrm{K}_{2} \mathrm{O}$ vs. $\mathrm{Na}_{2} \mathrm{O}$ c $-\mathrm{TiO}_{2}$ vs. $\mathrm{Al}_{2} \mathrm{O}_{3} ; \mathbf{d}-\mathrm{K}_{2} \mathrm{O}$ vs. $\mathrm{Ba}$; $\mathbf{e}-\mathrm{Zr}$ vs. Hf; $\mathbf{f}-\mathrm{Sc}$ vs. Ga.

of metapelites (Sylvester 1998; Inger and Harris 1993). The $\mathrm{Zr} / \mathrm{Hf}$ ratios (18-30; Tab. 3) are characteristic of anatectic granites (Dostal and Chatterjee 2000; Gao et al. 2017) and the HFSE contents are close to, or lower than, those in the bulk continental crust (Taylor and McLennan 1995).

Chondrite-normalized REE patterns (Fig. 5a) show a slight enrichment in LREE $\left(\mathrm{La}_{\mathrm{N}} / \mathrm{Yb}_{\mathrm{N}}=2.3-8.0\right)$ and negative $\mathrm{Eu}$ anomalies $\left(\mathrm{Eu} / \mathrm{Eu}^{*}=0.4-0.8\right)$. Also the leucocratic halos display comparable total REE contents and chondrite-normalized REE patterns (Fig. 5b). Typical are variable negative, or even absent, Eu anomalies $\left(\mathrm{Eu} / \mathrm{Eu}^{*}=0.7-1.0\right.$; Fig. $\left.5 b\right)$. Tourmaline granites show low contents of $\mathrm{Zr}$ and $\mathrm{Hf}$ (Fig. 4e), whereas these values in the nodules are similar to the host MBG. Both tourmaline-bearing granites and nodules are enriched in $\mathrm{Ga}$ and Sc (Fig. 4f). Chondrite-normalized REE patterns of TN ( $\sum$ REE 32-53 ppm) resemble those from host MBG (Fig. 5b) with small LREE enrichment $\left(\mathrm{La}_{\mathrm{N}} / \mathrm{Yb}_{\mathrm{N}}\right.$ $=1.9-5.9)$ but deeper negative Eu anomalies $\left(\mathrm{Eu} / \mathrm{Eu}^{*} \stackrel{N}{=}\right.$ $0.2-0.5$ ). Tourmaline-bearing granites are characterized by the lowest REE contents ( $\sum$ REE 16-19 ppm) of all granite types and the shape of chondrite-normalized REE patterns $\left(\mathrm{La}_{\mathrm{N}} / \mathrm{Yb}_{\mathrm{N}}=3.0-4.6 ; \mathrm{Eu} / \mathrm{Eu}^{*}=0.3-0.6\right)$ seems to be affected by the M-type tetrad effect (Irber 1999).

The leucocratic halos are depleted in $\mathrm{TiO}_{2}, \mathrm{Fe}_{2} \mathrm{O}_{3}$ t, $\mathrm{MgO}$ and Sc relative to MBG, but show comparable concentrations of some major- and trace elements $\left(\mathrm{Ga}, \mathrm{Na}_{2} \mathrm{O}\right.$, $\mathrm{K}_{2} \mathrm{O}, \mathrm{Rb}$ and Cs; Fig 6a; Tabs 2-3). Tourmaline nodules are significantly enriched in $\mathrm{TiO}_{2}, \mathrm{Fe}_{2} \mathrm{O}_{3} \mathrm{t}, \mathrm{MgO}, \mathrm{Ga}$ and 
Tab. 3 Trace-element analyses of selected samples (ppm)

\begin{tabular}{|c|c|c|c|c|c|c|c|c|c|c|c|c|c|c|c|}
\hline \multirow{2}{*}{$\begin{array}{l}\text { Sample } \\
\text { Rocks }\end{array}$} & \multirow{2}{*}{ GB12/9 } & $\mathrm{GB} 40 / \mathrm{G}$ & GB41 & \multicolumn{2}{|c|}{ GB42/O GB35/6 } & \multicolumn{5}{|c|}{ GB12/L GB40/L GB42/L 35GB/L GB35/L6 } & \multicolumn{3}{|c|}{ GB12/N GB40/N GB42/N } & \multirow{2}{*}{\multicolumn{2}{|c|}{$\frac{\text { GB42/B GB35/T2 }}{\text { Tourmaline granite }}$}} \\
\hline & & \multicolumn{4}{|c|}{ Muscovite-biotite granites } & \multicolumn{5}{|c|}{ Leucocratic haloes } & \multicolumn{3}{|c|}{ Tourmaline nodules } & & \\
\hline $\mathrm{Ba}$ & 247.1 & 173.1 & 167.4 & 207.3 & 138.3 & 199.6 & 616.8 & 405.9 & 408.0 & 122.5 & 21.4 & 113.8 & 99.3 & 49.3 & 108.6 \\
\hline Co & 0.6 & $<0.5$ & 0.6 & 0.9 & 0.7 & $<0.5$ & $<0.5$ & $<0.5$ & 1.6 & $<0.5$ & 4.0 & 3.6 & 3.9 & $<0.5$ & 1.4 \\
\hline $\mathrm{Cu}$ & 1.4 & 2.0 & 1.0 & 1.1 & 7.7 & 0.5 & 0.4 & 0.5 & 5.6 & 1.5 & 2.2 & 0.7 & 1.7 & 0.3 & 2.9 \\
\hline $\mathrm{Ni}$ & 2.5 & 4.3 & 6.1 & 3.6 & 3.7 & 0.8 & 1.0 & 1.5 & 6.8 & 1.6 & 2.7 & 1.7 & 2.3 & 0.6 & 3.4 \\
\hline $\mathrm{Rb}$ & 320.4 & 213.5 & 233.3 & 207.5 & 345.6 & 356.2 & 226.6 & 191.9 & 258.4 & 325.4 & 246.0 & 63.8 & 94.4 & 278.2 & 248.2 \\
\hline $\mathrm{Sr}$ & 62.9 & 71.3 & 62.5 & 68.8 & 44.7 & 66.3 & 156.1 & 115.7 & 116.1 & 46.1 & 21.8 & 38.5 & 40.2 & 21.7 & 43.3 \\
\hline $\mathrm{V}$ & 7 & 9 & $<5$ & $<5$ & $<5$ & $<5$ & $<5$ & $<5$ & 9 & $<5$ & 24 & 11 & 6 & $<5$ & $<5$ \\
\hline $\mathrm{Sn}$ & 8 & 9 & 14 & 13 & 22 & 5 & 4 & 8 & 14 & 9 & 5 & 6 & 8 & 39 & 8 \\
\hline $\mathrm{Zn}$ & 8 & 10 & 15 & 10 & 16 & 2 & 2 & 3 & 13 & 7 & 9 & 2 & 9 & 1 & 4 \\
\hline As & 1.2 & 1.0 & 1.7 & 4.7 & 18.9 & 0.7 & 0.5 & 0.8 & 16.2 & 1.9 & 1.1 & 1.0 & 5.8 & 3.8 & 2.1 \\
\hline $\mathrm{U}$ & 4.0 & 5.7 & 2.1 & 4.6 & 3.0 & 4.2 & 4.3 & 1.7 & 3.8 & 2.3 & 4.4 & 3.8 & 2.5 & 2.3 & 2.1 \\
\hline $\mathrm{Nb}$ & 16.2 & 9.2 & 10.3 & 7.4 & 12.3 & 18.0 & 3.2 & 1.3 & 11.0 & 10.6 & 1.7 & 1.1 & 0.9 & 22.5 & 2.6 \\
\hline Mo & 0.1 & 0.1 & 0.1 & 0.1 & 0.1 & $<0.1$ & $<0.1$ & $<0.1$ & 0.1 & $<0.1$ & $<0.1$ & $<0.1$ & 0.1 & $<0.1$ & $<0.1$ \\
\hline $\mathrm{Y}$ & 14.5 & 10.7 & 12.6 & 11.7 & 13.1 & 11.5 & 17.9 & 16.2 & 19.2 & 7.9 & 8.9 & 12.8 & 20.0 & 5.2 & 7.2 \\
\hline $\mathrm{Zr}$ & 46.0 & 43.8 & 29.7 & 35.3 & 34.8 & 34.5 & 51.5 & 34.5 & 59.1 & 21.9 & 30.5 & 46.7 & 40.1 & 27.7 & 15.6 \\
\hline $\mathrm{Pb}$ & 9.7 & 9.3 & 8.4 & 9.5 & 13.6 & 14.3 & 13.2 & 3.2 & 7.1 & 19.3 & 7.1 & 6.3 & 5.2 & 7.7 & 13.6 \\
\hline $\mathrm{Cd}$ & $<0.1$ & $<0.1$ & 0.1 & $<0.1$ & 0.1 & $<0.1$ & $<0.1$ & $<0.1$ & 0.1 & $<0.1$ & $<0.1$ & $<0.1$ & 0.1 & $<0.1$ & $<0.1$ \\
\hline Cs & 14.0 & 16.5 & 18.6 & 18.8 & 36.7 & 12.2 & 12.4 & 12.7 & 57.2 & 9.6 & 8.9 & 4.3 & 6.5 & 25.1 & 6.0 \\
\hline Th & 4.2 & 11.3 & 1.3 & 6.1 & 2.8 & 4.4 & 14.5 & 2.1 & 9.1 & 2.2 & 4.0 & 12.2 & 1.6 & 2.8 & 0.8 \\
\hline Ta & 4.3 & 1.4 & 2.2 & 1.8 & 2.4 & 4.6 & 0.9 & 0.4 & 2.2 & 2.5 & 1.3 & 0.7 & 0.8 & 4.3 & 0.9 \\
\hline $\mathrm{Hf}$ & 2.2 & 2.1 & 1.2 & 2.0 & 1.8 & 1.1 & 2.1 & 1.2 & 2.0 & 1.2 & 1.3 & 2.0 & 1.5 & 1.7 & 0.9 \\
\hline $\mathrm{Sc}$ & 5 & 3 & 3 & 2 & 3 & 2 & $<1$ & $<1$ & 4 & 2 & 26 & 15 & 10 & 9 & 11 \\
\hline $\mathrm{Sb}$ & $<0.1$ & $<0.1$ & 0.1 & 0.1 & 1.0 & $<0.1$ & 0.1 & 0.1 & 0.2 & 0.1 & $<0.1$ & 0.2 & 0.1 & 0.4 & 0.1 \\
\hline $\mathrm{Ag}$ & $<0.1$ & $<0.1$ & $<0.1$ & $<0.1$ & $<0.1$ & $<0.1$ & $<0.1$ & $<0.1$ & $<0.1$ & $<0.1$ & $<0.1$ & $<0.1$ & $<0.1$ & $<0.1$ & $<0.1$ \\
\hline $\mathrm{Hg}$ & $<0.01$ & 0.01 & $<0.01$ & 0.01 & 0.01 & $<0.01$ & $<0.01$ & $<0.01$ & $<0.01$ & 0.01 & $<0.01$ & $<0.01$ & $<0.01$ & $<0.01$ & 0.01 \\
\hline $\mathrm{Tl}$ & 0.1 & 0.2 & 0.2 & 0.1 & 0.4 & 0.1 & $<0.1$ & $<0.1$ & 0.4 & 0.5 & 0.2 & $<0.1$ & 0.1 & 0.1 & 0.2 \\
\hline $\mathrm{Bi}$ & 0.1 & 0.4 & 0.5 & 0.9 & 1.2 & 0.1 & 0.1 & 5.0 & 0.3 & 0.9 & 0.3 & 0.4 & 42.3 & 1.1 & 1.7 \\
\hline W & 4.6 & 1.4 & 1.6 & 3.3 & 3.2 & 3.3 & 0.4 & 0.9 & 3.4 & 2.0 & 1.1 & 0.5 & 1.6 & 7.5 & 0.8 \\
\hline $\mathrm{Ga}$ & 17.6 & 18.9 & 13.8 & 17.3 & 19.5 & 16.1 & 15.0 & 10.8 & 17.4 & 16.4 & 43.8 & 40.3 & 30.9 & 26.9 & 30.7 \\
\hline $\mathrm{La}$ & 7.2 & 9.3 & 4.5 & 5.5 & 5.0 & 7.0 & 13.2 & 5.5 & 14.6 & 5.3 & 5.8 & 10.3 & 5.4 & 3.0 & 2.6 \\
\hline $\mathrm{Ce}$ & 16.6 & 18.2 & 9.6 & 11.6 & 11.7 & 13.9 & 26.5 & 12.9 & 31.1 & 10.3 & 13.1 & 22.1 & 12.9 & 5.6 & 6.7 \\
\hline $\operatorname{Pr}$ & 1.89 & 2.05 & 1.03 & 1.26 & 1.30 & 1.60 & 2.88 & 1.43 & 3.29 & 1.20 & 1.53 & 2.52 & 1.52 & 0.66 & 0.84 \\
\hline $\mathrm{Nd}$ & 6.5 & 6.6 & 3.7 & 4.2 & 4.8 & 4.9 & 10.6 & 4.6 & 12.5 & 4.1 & 5.5 & 8.8 & 5.4 & 2.3 & 3.1 \\
\hline $\mathrm{Sm}$ & 1.5 & 1.7 & 1.3 & 1.2 & 1.3 & 1.4 & 2.3 & 1.5 & 2.9 & 1.0 & 1.1 & 1.8 & 1.7 & 0.8 & 1.0 \\
\hline $\mathrm{Eu}$ & 0.37 & 0.14 & 0.25 & 0.16 & 0.29 & 0.36 & 0.49 & 0.50 & 0.75 & 0.21 & 0.07 & 0.20 & 0.31 & 0.07 & 0.20 \\
\hline $\mathrm{Gd}$ & 1.76 & 1.48 & 1.30 & 1.30 & 1.36 & 1.27 & 2.25 & 1.47 & 2.57 & 0.97 & 0.84 & 1.65 & 2.04 & 0.73 & 1.03 \\
\hline $\mathrm{Tb}$ & 0.43 & 0.31 & 0.30 & 0.31 & 0.34 & 0.34 & 0.47 & 0.35 & 0.53 & 0.26 & 0.20 & 0.32 & 0.47 & 0.17 & 0.27 \\
\hline Dy & 2.26 & 1.96 & 2.08 & 1.98 & 2.15 & 1.71 & 3.00 & 2.45 & 3.07 & 1.46 & 1.37 & 2.24 & 3.41 & 0.95 & 1.40 \\
\hline Ho & 0.43 & 0.34 & 0.38 & 0.33 & 0.41 & 0.34 & 0.57 & 0.54 & 0.63 & 0.27 & 0.23 & 0.42 & 0.67 & 0.15 & 0.21 \\
\hline Er & 1.40 & 1.06 & 1.30 & 1.18 & 1.17 & 1.09 & 1.77 & 1.67 & 1.82 & 0.68 & 0.81 & 1.28 & 2.11 & 0.46 & 0.54 \\
\hline Tm & 0.18 & 0.14 & 0.18 & 0.14 & 0.19 & 0.17 & 0.24 & 0.25 & 0.28 & 0.11 & 0.14 & 0.18 & 0.30 & 0.08 & 0.10 \\
\hline $\mathrm{Yb}$ & 1.45 & 0.96 & 1.34 & 0.98 & 1.17 & 0.98 & 1.53 & 1.67 & 1.75 & 0.58 & 0.82 & 1.17 & 1.92 & 0.44 & 0.58 \\
\hline $\mathrm{Lu}$ & 0.19 & 0.14 & 0.18 & 0.14 & 0.15 & 0.18 & 0.22 & 0.23 & 0.25 & 0.09 & 0.16 & 0.17 & 0.26 & 0.06 & 0.08 \\
\hline $\mathrm{Rb} / \mathrm{Sr}$ & 5.1 & 3.0 & 3.7 & 3.0 & 7.7 & 5.4 & 1.5 & 1.7 & 2.2 & 7.1 & 11.3 & 1.7 & 2.3 & 12.8 & 5.7 \\
\hline $\mathrm{Rb} / \mathrm{Ba}$ & 1.3 & 1.2 & 1.4 & 1.0 & 2.5 & 1.8 & 0.4 & 0.5 & 0.6 & 2.7 & 11.5 & 0.6 & 1.0 & 5.6 & 2.3 \\
\hline $\mathrm{Zr} / \mathrm{Hf}$ & 20.9 & 20.9 & 24.8 & 17.7 & 19.3 & 31.4 & 24.5 & 28.8 & 29.6 & 18.3 & 23.5 & 23.4 & 26.7 & 16.3 & 17.3 \\
\hline $\mathrm{Eu} / \mathrm{Eu}^{*}$ & 0.70 & 0.27 & 0.59 & 0.39 & 0.67 & 0.83 & 0.66 & 1.03 & 0.84 & 0.65 & 0.22 & 0.35 & 0.51 & 0.28 & 0.60 \\
\hline $\mathrm{La}_{\mathrm{N}} / \mathrm{Yb}_{\mathrm{N}}$ & 3.3 & 6.5 & 2.3 & 3.8 & 2.9 & 4.8 & 5.8 & 2.2 & 5.6 & 6.2 & 4.8 & 5.9 & 1.9 & 4.6 & 3.0 \\
\hline$\sum \mathrm{REE}$ & 42.2 & 44.4 & 27.4 & 30.3 & 31.3 & 35.2 & 66.0 & 35.1 & 76.0 & 26.5 & 31.7 & 53.2 & 38.4 & 15.5 & 18.7 \\
\hline
\end{tabular}

depleted in $\mathrm{Na}_{2} \mathrm{O}, \mathrm{K}_{2} \mathrm{O}, \mathrm{Ba}, \mathrm{Rb}, \mathrm{Sr}$, and $\mathrm{Cs}$ (Fig. 6b). Tourmaline-bearing granites are enriched in $\mathrm{Fe}_{2} \mathrm{O}_{3} \mathrm{t}, \mathrm{Ga}$ and $\mathrm{Sc}$ and depleted in $\mathrm{Ba}$ and $\mathrm{Sr}$ (Fig. 6b). Contents of major elements, B, and F from LH and TN (Fig. 7) are compared with their host rocks (MBG) in isocon plots (Grant 1986; Selverstone and Hyatt 2003). In order to define the best fit isocon, $\mathrm{Al}_{2} \mathrm{O}_{3}$ was chosen as immobile constituent. Isocons close to the 1:1 mass line are for the $\mathrm{LH}$, whereas 
isocons for the TN lie to the left of the $1: 1$ lines indicating that the chemical changes were likely connected with mass loss (e.g., Grant 1986) or $\mathrm{Al}_{2} \mathrm{O}_{3}$ enrichment in the TN (B-rich residual melt). The halos do not show any significant changes except for iron losses. Characteristic of the tourmaline nodules is enrichment in $\mathrm{Fe}_{2} \mathrm{O}_{3}, \mathrm{MgO}$, $\mathrm{B}$ and depletion in $\mathrm{Na}_{2} \mathrm{O}, \mathrm{K}_{2} \mathrm{O}$ and, to some extent, $\mathrm{SiO}_{2}$.

A tourmaline nodule sample from locality Březka (Tab. 1) provided $\delta^{18} \mathrm{O}$ of $+8.9 \%$, whereas LH and MBG have slightly lower values of +7.1 and $+7.7 \%$, respectively (Tab. 2). The isotopic composition of MBG is comparable to other Variscan peraluminous granites from Western Europe (e.g., Hoefs and Emmermann 1983; Vellmer and Wedepohl 1994).

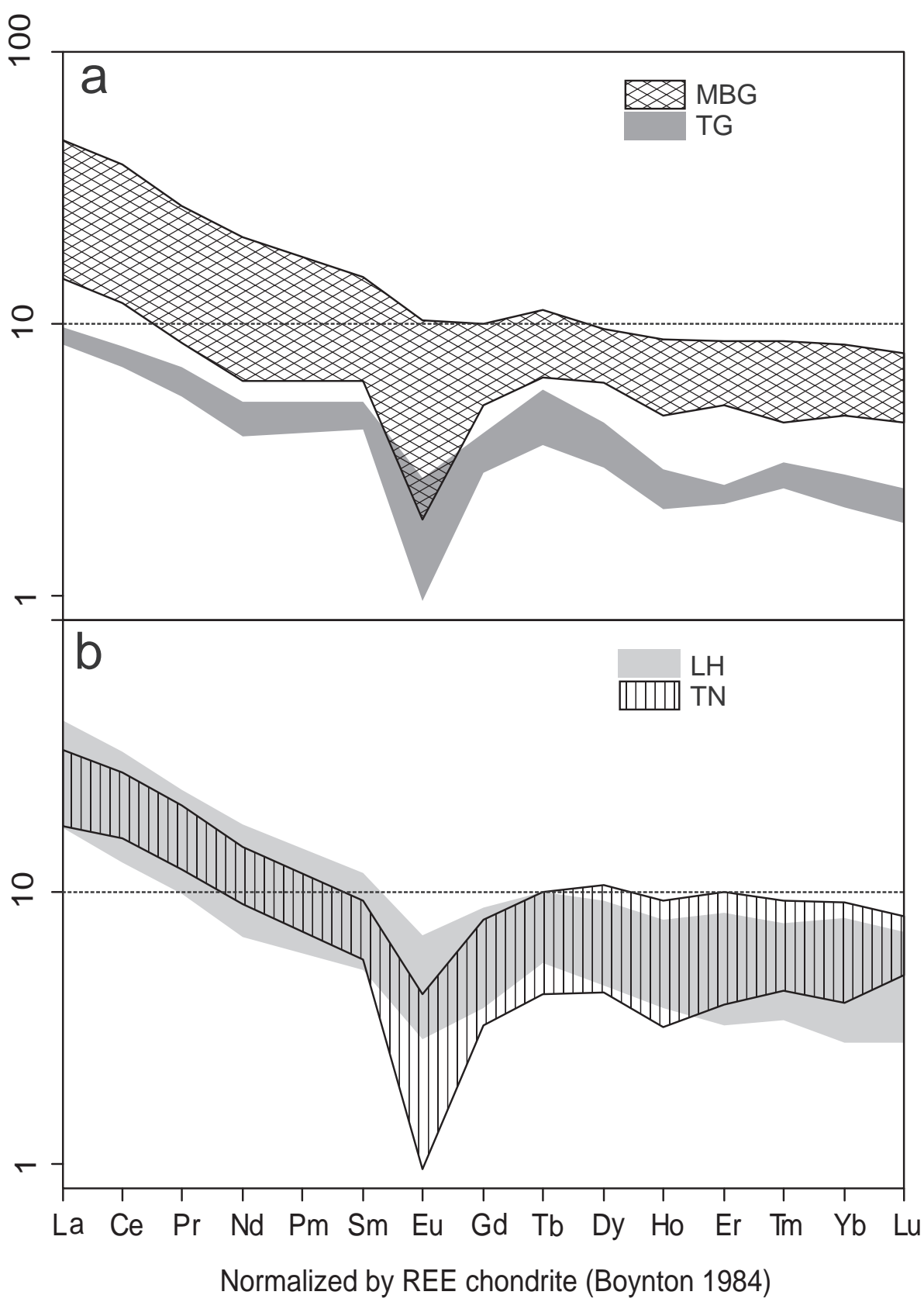

The zircon saturation temperatures (Watson and Harrison 1983) are $700-668^{\circ} \mathrm{C}$ for $\mathrm{MBG}$ and $675-641{ }^{\circ} \mathrm{C}$ for tourmaline-bearing granite, respectively, and similar are also monazite saturation temperatures (Montel 1993): $703-662^{\circ} \mathrm{C}$ and $680-658^{\circ} \mathrm{C}$ (Tab. 2).

\subsection{Mineral chemistry}

\subsubsection{Feldspars}

The contents of anorthite component in plagioclase and albite component in $\mathrm{K}$-feldspar are given in the petrographic description (Chapter 4.1.). Minor $\mathrm{P}_{2} \mathrm{O}_{5}$ concentrations vary from rather high in K-feldspar phenocrysts (Fig. 8 a) of pegmatites with tourmaline $(0.28-0.68$ wt. \%) and host MBG (0.10-0.43 wt. \%) to rather low in TN and LH $(0.02-0.36$ wt. \%). The P contents decrease with increasing intensity of sericitization. Concentrations of $\mathrm{BaO}$ are mostly below detection limit, except for marginal parts of some K-feldspars grains in the $\mathrm{TN}$ (up to 0.58 wt. \%).

\subsubsection{Biotite}

Biotite from granitic rocks has rather constant ${ }^{\mathrm{IV}} \mathrm{Al}$ of 2.58 2.77 apfu (Fig. 8b). However, it differs in $\mathrm{X}_{\mathrm{Fe}}$ and $\mathrm{F}$ contents $0.81-0.91$ and $0.10-0.19$ apfu in pegmatites with tourmaline and $0.69-0.82$ and $0.21-0.26$ in the host MBG, respectively. Biotite (Tab. 4) from restitic enclaves has lower $\mathrm{X}_{\mathrm{Fe}}$ (0.49-0.55) and ${ }^{\mathrm{IV}} \mathrm{Al}(2.26-$ $2.50 \mathrm{apfu}$ ). Late (subsolidus?) biotite $\left(\mathrm{X}_{\mathrm{Fe}}=0.73-0.74\right)$ of the fractures cutting the tourmalines in the nodules shows variable ${ }^{\mathrm{IV}} \mathrm{Al}(2.26-2.71 \mathrm{apfu})$ and very low $\mathrm{F}$ (0.01-0.08 apfu). The Ti contents vary

Fig. 5 Chondrite-normalized (Boynton 1984) REE patterns for muscovite-biotite and tourmaline granites (a), tourmaline nodules and leucocratic halos (b). 
Fig. 6 Multi-element diagrams normalized to the parental muscovite-biotite granite for leucocratic halos (a), tourmaline nodules and tourmaline granites (b).

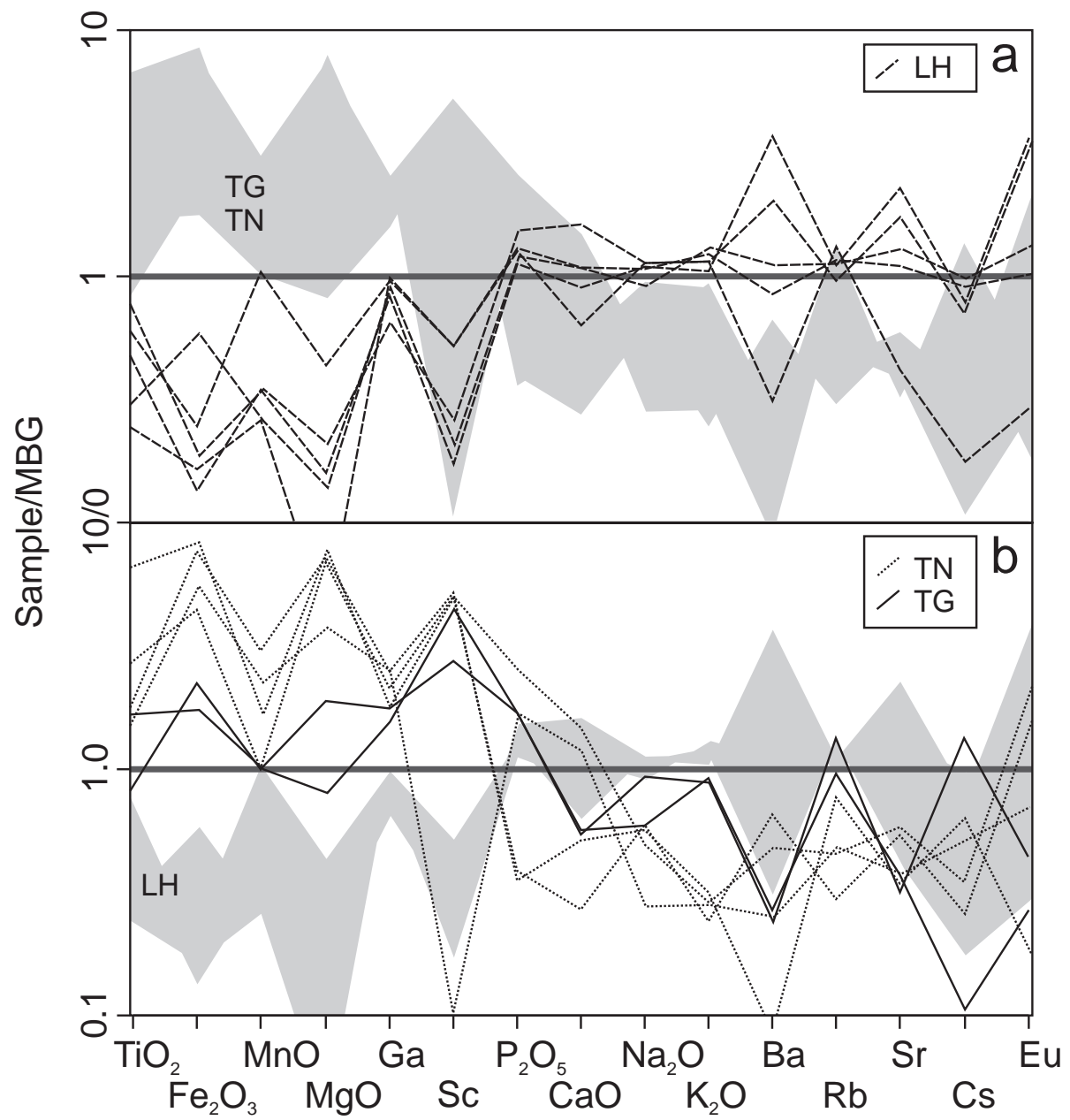

from 0.15 to 0.43 apfu in MBG up to 0.53 apfu in tourmaline pegmatites.

\subsubsection{Tourmaline}

The large diversity of textural types of tourmalines is reflected in the high variability of their chemical composition (Fig. 9). The occupation of T-site is variable (5.71-6.05 apfu Si) but commonly close to the ideal stoichiometry $(\mathrm{Si}=6)$. In all analyses (Tab. 5) Z-site is fully occupied by Al ( $\mathrm{Al}_{\text {tot }}$ 5.98-7.00 apfu). The Na content varies from 0.31 to $0.76 \mathrm{apfu}$; on the other hand, contents of $\mathrm{Ca}(\leq 0.10 \mathrm{apfu})$ and $\mathrm{K}(\leq 0.05 \mathrm{apfu})$ are low (Fig. 9a). Tourmaline also displays considerable variations in $\mathrm{Mg}$ (0.03 to $1.51 \mathrm{apfu}$ ) and Fe (0.89 to $2.18 \mathrm{apfu,} \mathrm{Fig.} \mathrm{9b)} \mathrm{but}$ low contents of $\mathrm{Mn}(\leq 0.06 \mathrm{apfu})$ and $\mathrm{Ti}(\leq 0.21 \mathrm{apfu})$. Most tourmalines are F-poor, but some have moderate $\mathrm{F}$ contents (up to $0.34 \mathrm{apfu}$ ).

The compositional changes in tourmaline are expressed by combination of four main substitutions (Fig. 9c-f). The homovalent substitution (1) $\mathrm{Fe} \mathrm{Mg}_{-1}$ is dominant (Fig. 9d, f). Alkali-deficiency suggests participation of the heterovalent substitutions (2) ${ }^{\mathrm{X}} \mathrm{Na}^{\mathrm{Y}} \mathrm{R}^{2+\mathrm{W}} \mathrm{F}{ }^{\mathrm{X}} \square{ }^{\mathrm{Y}} \mathrm{Al}_{-1}{ }^{\mathrm{W}}$
$\mathrm{OH}_{-1}$ and/or (3) ${ }^{\mathrm{X}} \mathrm{Na}^{\mathrm{Y}} \mathrm{R}^{2+}{ }^{\mathrm{X}} \square{ }^{\mathrm{Y}} \mathrm{Al}$, which are combined with the substitution (4) ${ }^{\mathrm{Y}} \mathrm{R}^{2+\mathrm{W}} \mathrm{OH}^{-}{ }^{\mathrm{Y}} \mathrm{Al}_{-1}{ }^{\mathrm{W}} \mathrm{O}_{-1}$ (Fig. 9c-f). Formula calculations yielded low $\sum^{-1} \mathrm{Y}$ and commonly high ${ }^{\mathrm{Y}} \mathrm{Al}$ (Tab. 5) indicating significant participation of substitution (4) and abundance of oxy-tourmaline components. Oxy-schorl is a typical tourmaline of various peraluminous granites (e. g. Novák et al. 2004; Bačík et al. 2013).

The tourmalines are almost homogeneous, showing fine oscillatory or patchy zoning (Fig. $3 \mathrm{a}-\mathrm{d}$ ). Three main types of tourmaline were defined based on their textural relations and chemical composition (Fig. 9):

(I) Anhedral to subhedral tourmaline grains in $\mathrm{TN}$ and TNV are typically interstitial between quartz and feldspars or replace plagioclases and albite perthites in K-feldspars. They contain homogeneous draviterich core and oscillatory-zoned rim with dominating (2) and often also (3) substitutions ( $\mathrm{Na} \mathrm{0.31-0.66,} \mathrm{Mg}$ 0.07-0.95, Al 6.36-7.00, apfu; Fig. 9c-e). The composition of homogeneous tourmaline cores in TN resembles that of skeletal crystals. The main trends from core to rim are parallel to $(3,4)$ and sporadically $(2)$ substitutions (Fig. 9c). 

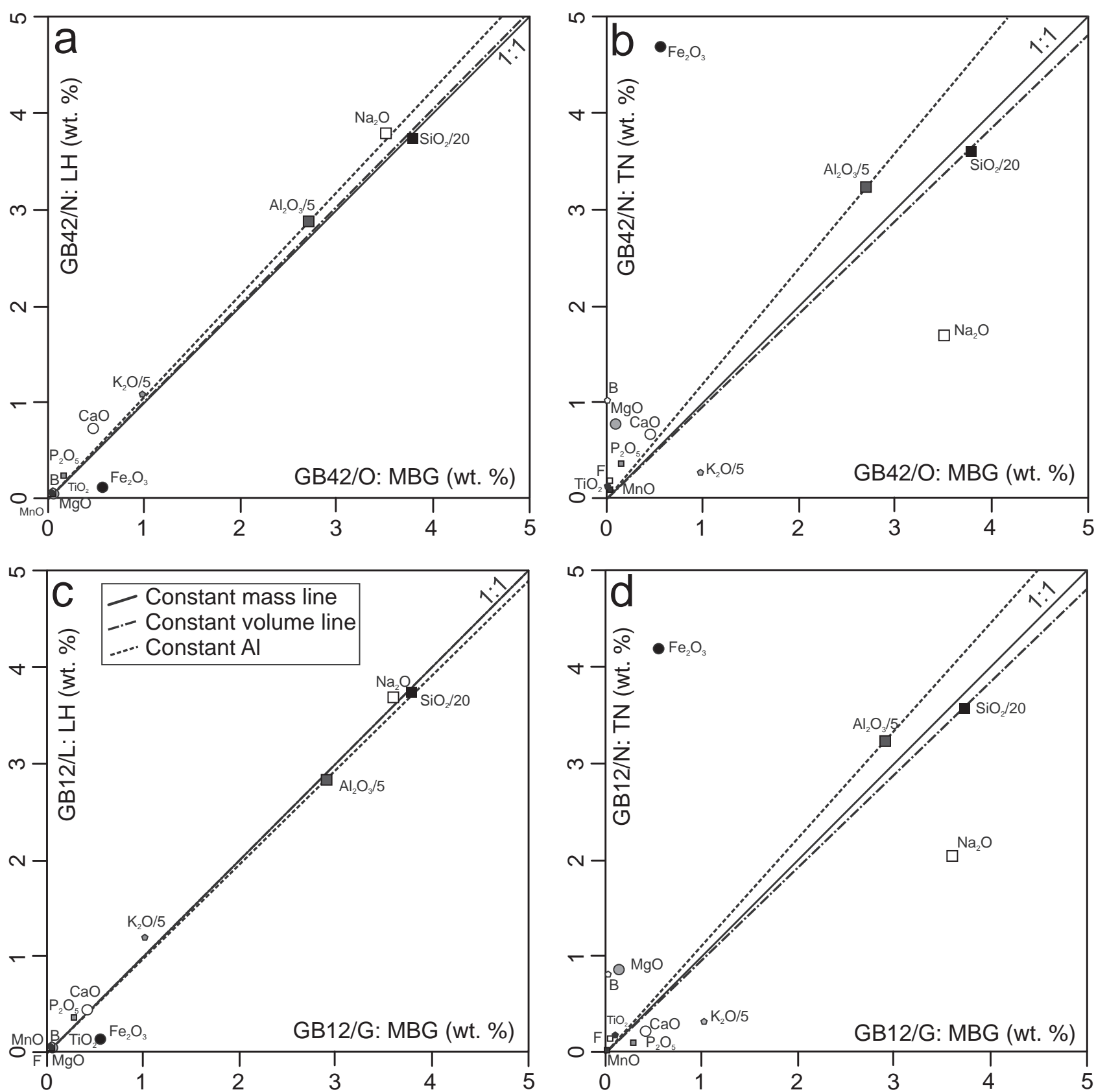

Fig. 7 Isocon diagrams for samples from Svatoslav (a, b) and Březka (c, d), comparing muscovite-biotite granite (MBG) with leucocratic halos $(\mathrm{LH} ; \mathbf{a}, \mathbf{c})$ and tourmaline nodules $(\mathrm{TN} ; \mathbf{b}, \mathbf{d})$.

(II) Euhedral to subhedral columnar grains of tourmaline randomly distributed in tourmaline-bearing granite are patchy zoned (Fig. 3d) with dominating (3) substitution (Na 0.44-0.76, Mg 0.05-1.51, Al 5.98-6.95 apfu; Fig. 9c-e). The chemical evolution of internal zones of crystals (Na 0.32-0.43, Al 6.75-6.92 apfu) follows the same substitution mechanism (3).

(III) Columnar and needle-like crystals from central part of tourmaline pegmatite dykes are oscillatory zoned, F-poor tourmaline. In tourmaline crystals $\mathrm{Na}(0.31-0.61$ apfu) with $\mathrm{Fe}$ (1.16-2.18 apfu) increase and $\mathrm{Al}$ with $\mathrm{Mg}$ decrease (6.41-6.95 and 0.03-1.25 apfu respectively) outwards (Fig. 9e-f). Most crystals are overgrown by younger dravite-rich rim (up to $0.2 \mathrm{~mm}$ thick) with high $\mathrm{Mg}(1.21-1.38 \mathrm{apfu})$ and low $\mathrm{Fe}(<1.4 \mathrm{apfu})$ contents (Fig. 9f).

\subsubsection{Accessory minerals}

Three different compositional and textural types of

fluorapatite were identified. Euhedral grains of apatite I $(50-100 \mu \mathrm{m})$ in $\mathrm{MBG}$ and tourmaline-bearing granite 
Tab. 4 Representative chemical compositions of micas (wt. \% and apfu; structural formulae on the basis of $22 \mathrm{O}$ )

\begin{tabular}{|c|c|c|c|c|c|c|c|c|c|c|c|c|}
\hline Locality & GB40/G & GB40/G & GB40/G & GB42/N & GB42/N & GB42/N & GB41/G & GB42/P & GB40/G & GB40/N & GB40/L & GB40/L \\
\hline rock type & MBG & MBG & MBG & MBG & MBG & MBG & MBG & ТP & MBG & MBG & LH & LH \\
\hline Mineral & $\mathrm{Bt}$ & $\mathrm{Bt}$ & $\mathrm{Bt}$ & $\mathrm{Bt}$ & $\mathrm{Bt}$ & $\mathrm{Bt}$ & Ms & Ms & Ms & Ms & Ms & Ms \\
\hline $\mathrm{SiO}_{2}$ & 33.50 & 33.66 & 35.78 & 35.93 & 33.38 & 34.74 & 47.12 & 47.25 & 46.37 & 46.31 & 45.27 & 45.35 \\
\hline $\mathrm{TiO}_{2}$ & 2.33 & 2.95 & 1.46 & 1.46 & 1.94 & 1.86 & 0.08 & 1.57 & 0.05 & 0.03 & 0.39 & 0.30 \\
\hline $\mathrm{Al}_{2} \mathrm{O}_{3}$ & 20.11 & 19.93 & 19.04 & 18.73 & 19.22 & 19.37 & 36.96 & 32.97 & 35.22 & 37.45 & 33.73 & 32.66 \\
\hline $\mathrm{FeO}$ & 26.88 & 25.63 & 24.73 & 19.04 & 28.23 & 23.48 & 0.59 & 1.28 & 1.79 & 0.34 & 4.10 & 4.69 \\
\hline $\mathrm{MnO}$ & 0.62 & 0.78 & 0.56 & 0.55 & 1.09 & 1.02 & 0.02 & 0.01 & 0.01 & 0.00 & 0.04 & 0.08 \\
\hline $\mathrm{MgO}$ & 3.36 & 3.62 & 4.82 & 9.35 & 2.10 & 5.79 & 0.08 & 1.37 & 0.33 & 0.06 & 0.84 & 1.14 \\
\hline $\mathrm{CaO}$ & 0.00 & 0.02 & 0.01 & 0.00 & 0.02 & 0.05 & 0.01 & 0.00 & 0.01 & 0.00 & 0.00 & 0.00 \\
\hline $\mathrm{Na}_{2} \mathrm{O}$ & 0.16 & 0.18 & 0.12 & 0.12 & 0.10 & 0.13 & 0.07 & 0.41 & 0.46 & 0.16 & 0.37 & 0.26 \\
\hline $\mathrm{K}_{2} \mathrm{O}$ & 9.23 & 9.33 & 9.56 & 9.65 & 9.25 & 9.37 & 10.44 & 10.65 & 10.85 & 10.65 & 10.94 & 11.01 \\
\hline $\mathrm{BaO}$ & 0.00 & 0.09 & 0.00 & 0.03 & 0.00 & 0.12 & 0.00 & 0.18 & 0.04 & 0.08 & 0.01 & 0.01 \\
\hline $\mathrm{Rb}_{2} \mathrm{O}$ & 0.10 & 0.00 & 0.00 & 0.12 & 0.18 & 0.02 & 0.02 & 0.00 & 0.05 & 0.00 & 0.00 & 0.00 \\
\hline $\mathrm{F}$ & 0.15 & 0.00 & 0.01 & 1.64 & 0.38 & 0.43 & 0.09 & 0.77 & 0.16 & 0.05 & 0.11 & 0.06 \\
\hline $\mathrm{Cl}$ & 0.06 & 0.05 & 0.00 & 0.03 & 0.03 & 0.04 & 0.01 & 0.01 & 0.01 & 0.00 & 0.00 & 0.01 \\
\hline $\mathrm{H}_{2} \mathrm{O}^{*}$ & 3.73 & 3.82 & 3.87 & 3.13 & 3.56 & 3.65 & 4.51 & 4.14 & 4.41 & 4.51 & 4.39 & 4.38 \\
\hline $\mathrm{O}=\mathrm{F}, \mathrm{Cl}$ & -0.08 & -0.01 & 0.00 & -0.70 & -0.17 & -0.19 & -0.04 & -0.33 & -0.07 & -0.02 & -0.04 & -0.03 \\
\hline Total & 100.15 & 100.04 & 99.94 & 99.08 & 99.31 & 99.87 & 99.94 & 100.30 & 99.66 & 99.61 & 100.12 & 99.92 \\
\hline$\overline{\mathrm{Si}}$ & 5.260 & 5.264 & 5.545 & 5.497 & 5.345 & 5.388 & 6.205 & 6.279 & 6.202 & 6.129 & 6.117 & 6.164 \\
\hline $\mathrm{Al}^{\mathrm{IV}}$ & 2.740 & 2.736 & 2.455 & 2.503 & 2.655 & 2.612 & 1.795 & 1.721 & 1.798 & 1.871 & 1.883 & 1.836 \\
\hline $\mathrm{Al}^{\mathrm{VI}}$ & 0.980 & 0.938 & 1.022 & 0.874 & 0.972 & 0.928 & 3.942 & 3.443 & 3.755 & 3.971 & 3.489 & 3.396 \\
\hline $\mathrm{Ti}$ & 0.275 & 0.347 & 0.170 & 0.168 & 0.234 & 0.217 & 0.008 & 0.157 & 0.005 & 0.003 & 0.040 & 0.031 \\
\hline $\mathrm{Fe}$ & 3.529 & 3.353 & 3.204 & 2.436 & 3.781 & 3.045 & 0.065 & 0.142 & 0.200 & 0.038 & 0.463 & 0.533 \\
\hline $\mathrm{Mn}$ & 0.083 & 0.103 & 0.073 & 0.071 & 0.147 & 0.134 & 0.002 & 0.001 & 0.001 & 0.000 & 0.004 & 0.009 \\
\hline $\mathrm{Mg}$ & 0.785 & 0.844 & 1.113 & 2.132 & 0.501 & 1.339 & 0.015 & 0.272 & 0.066 & 0.012 & 0.169 & 0.230 \\
\hline $\mathrm{Ca}$ & 0.000 & 0.003 & 0.001 & 0.000 & 0.003 & 0.007 & 0.002 & 0.000 & 0.001 & 0.000 & 0.000 & 0.000 \\
\hline $\mathrm{Na}$ & 0.049 & 0.054 & 0.037 & 0.035 & 0.031 & 0.038 & 0.017 & 0.106 & 0.119 & 0.040 & 0.097 & 0.069 \\
\hline K & 1.849 & 1.861 & 1.889 & 1.882 & 1.889 & 1.853 & 1.753 & 1.806 & 1.851 & 1.797 & 1.885 & 1.908 \\
\hline $\mathrm{Ba}$ & 0.000 & 0.005 & 0.000 & 0.002 & 0.000 & 0.007 & 0.000 & 0.009 & 0.002 & 0.004 & 0.000 & 0.000 \\
\hline $\mathrm{Rb}$ & 0.010 & 0.000 & 0.000 & 0.012 & 0.019 & 0.002 & 0.001 & 0.000 & 0.004 & 0.000 & 0.000 & 0.000 \\
\hline $\mathrm{OH}^{*}$ & 3.907 & 3.986 & 3.996 & 3.199 & 3.801 & 3.776 & 3.959 & 3.673 & 3.931 & 3.981 & 3.955 & 3.971 \\
\hline $\mathrm{F}$ & 0.076 & 0.000 & 0.004 & 0.794 & 0.190 & 0.212 & 0.039 & 0.325 & 0.068 & 0.019 & 0.045 & 0.027 \\
\hline $\mathrm{Cl}$ & 0.017 & 0.014 & 0.000 & 0.007 & 0.009 & 0.011 & 0.002 & 0.002 & 0.001 & 0.000 & 0.000 & 0.002 \\
\hline Total & 19.559 & 19.509 & 19.509 & 19.611 & 19.577 & 19.571 & 17.805 & 17.938 & 18.003 & 17.865 & 18.148 & 18.178 \\
\hline
\end{tabular}

* calculated from stoichiometry

Rock types: muscovite-biotite granites (MBG), tourmaline pegmatites (TP), leucocratic halos (LH)
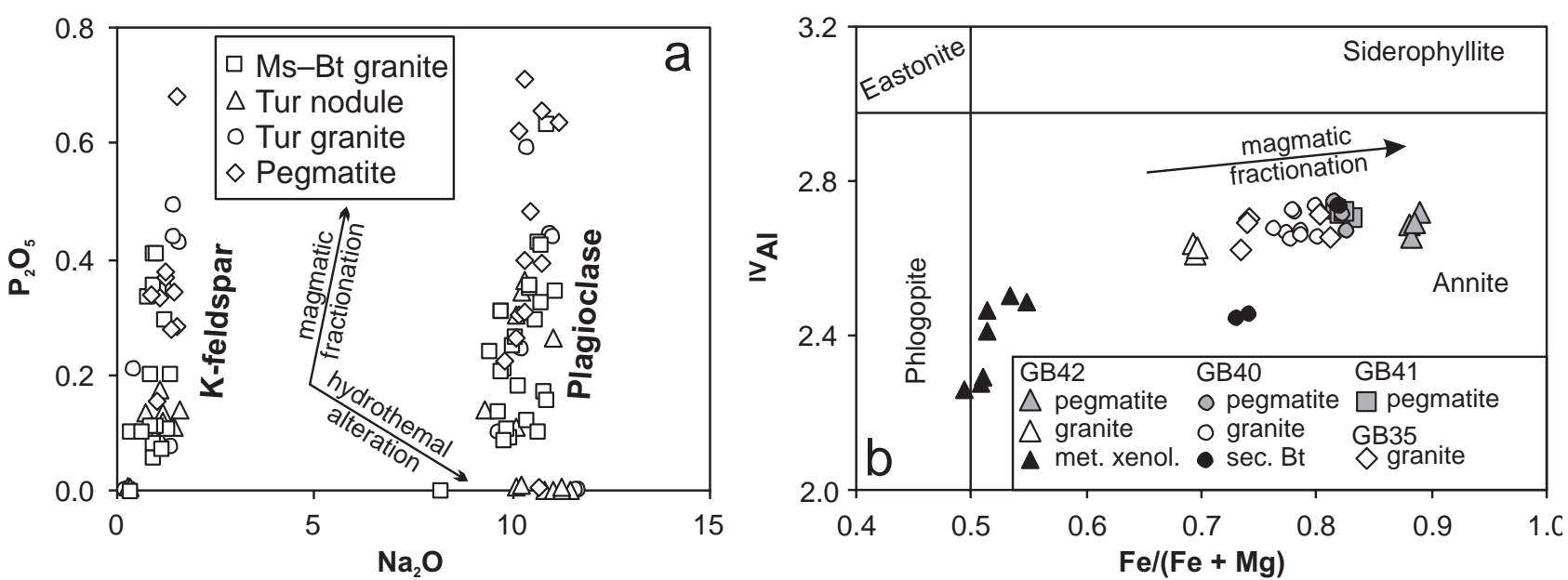

Fig. 8 Chemical composition of rock-forming minerals from pegmatites, tourmaline granites, tourmaline nodules and their parental granites: $\mathbf{a}-\mathrm{Na}_{2} \mathrm{O}$ vs. $\mathrm{P}_{2} \mathrm{O}_{5}$ diagram for the feldspars; $\mathbf{b}-\mathrm{Fe} /(\mathrm{Fe}+\mathrm{Mg})$ vs. $\mathrm{Al}^{\mathrm{IV}}$ diagram for the biotite. 
Tab. 5 Representative chemical compositions of tourmaline from pegmatites and quartz-tourmaline veins (wt. \% and apfu; structural formulae on the basis of $31(\mathrm{O}, \mathrm{OH}, \mathrm{F}))$

\begin{tabular}{|c|c|c|c|c|c|c|c|c|c|c|c|}
\hline Locality & $\mathrm{GB} 40 / \mathrm{N}$ & GB40/N & $\mathrm{GB} 40 / \mathrm{N}$ & GB41/N & $\mathrm{GB} 42 / \mathrm{P}$ & $\mathrm{GB} 42 / \mathrm{P}$ & GB35/T2 & GB35/T2 & $\mathrm{GB} 12 / \mathrm{N}$ & $\mathrm{GB} 12 / \mathrm{N}$ & $\mathrm{GB} 12 / \mathrm{N}$ \\
\hline rock type & $\mathrm{TN}$ & $\mathrm{TN}$ & $\mathrm{TN}$ & $\mathrm{TN}$ & $\mathrm{TP}$ & $\mathrm{TP}$ & $\mathrm{TG}$ & $\mathrm{TG}$ & $\mathrm{TN}$ & $\mathrm{TN}$ & $\mathrm{TN}$ \\
\hline $\mathrm{SiO}_{2}$ & 34.99 & 35.40 & 34.41 & 36.41 & 35.51 & 35.45 & 35.50 & 35.00 & 35.14 & 35.54 & 35.14 \\
\hline $\mathrm{TiO}_{2}$ & 0.73 & 0.26 & 0.19 & 0.79 & 0.44 & 0.08 & 0.65 & 0.85 & 0.47 & 0.55 & 0.47 \\
\hline $\mathrm{Al}_{2} \mathrm{O}_{3}$ & 33.47 & 35.65 & 34.70 & 34.20 & 34.54 & 34.86 & 33.03 & 34.11 & 34.70 & 34.46 & 34.70 \\
\hline $\mathrm{V}_{2} \mathrm{O}_{3}$ & 0.00 & 0.00 & 0.00 & 0.00 & 0.00 & 0.00 & 0.00 & 0.00 & 0.00 & 0.00 & 0.00 \\
\hline $\mathrm{FeO}$ & 12.24 & 10.60 & 13.84 & 7.31 & 12.14 & 13.83 & 11.89 & 12.66 & 11.24 & 11.93 & 11.24 \\
\hline $\mathrm{MgO}$ & 2.40 & 2.26 & 1.04 & 5.08 & 1.59 & 0.41 & 2.87 & 1.61 & 2.13 & 1.49 & 2.13 \\
\hline $\mathrm{CaO}$ & 0.17 & 0.09 & 0.19 & 0.27 & 0.15 & 0.10 & 0.29 & 0.27 & 0.19 & 0.17 & 0.19 \\
\hline $\mathrm{MnO}$ & 0.17 & 0.11 & 0.24 & 0.04 & 0.14 & 0.19 & 0.15 & 0.14 & 0.15 & 0.15 & 0.15 \\
\hline $\mathrm{ZnO}$ & 0.00 & 0.00 & 0.00 & 0.00 & 0.00 & 0.00 & 0.07 & 0.07 & 0.00 & 0.00 & 0.00 \\
\hline $\mathrm{Na}_{2} \mathrm{O}$ & 1.67 & 1.56 & 1.25 & 1.70 & 1.41 & 1.17 & 1.76 & 1.60 & 1.79 & 1.69 & 1.79 \\
\hline $\mathrm{K}_{2} \mathrm{O}$ & 0.05 & 0.03 & 0.03 & 0.02 & 0.04 & 0.02 & 0.05 & 0.05 & 0.05 & 0.04 & 0.05 \\
\hline $\mathrm{F}$ & 0.58 & 0.28 & 0.27 & 0.07 & 0.23 & 0.11 & 0.36 & 0.15 & 0.25 & 0.35 & 0.25 \\
\hline $\mathrm{H}_{2} \mathrm{O}^{*}$ & 3.30 & 3.50 & 3.43 & 3.64 & 3.48 & 3.53 & 3.42 & 3.52 & 3.48 & 3.43 & 3.48 \\
\hline $\mathrm{B}_{2} \mathrm{O}_{3} *$ & 10.37 & 10.51 & 10.30 & 10.65 & 10.42 & 10.38 & 10.42 & 10.40 & 10.43 & 10.43 & 10.43 \\
\hline $\mathrm{O}=\mathrm{F}$ & -0.24 & -0.12 & -0.11 & -0.03 & -0.1 & -0.05 & -0.15 & -0.06 & -0.11 & -0.15 & -0.11 \\
\hline Total & 99.98 & 100.18 & 99.80 & 100.18 & 100.01 & 100.09 & 100.33 & 100.40 & 99.91 & 100.09 & 99.91 \\
\hline \multicolumn{12}{|l|}{ T site } \\
\hline $\mathrm{Si}^{4+}$ & 5.867 & 5.852 & 5.805 & 5.941 & 5.921 & 5.939 & 5.923 & 5.848 & 5.856 & 5.923 & 5.856 \\
\hline $\mathrm{Al}^{3+}$ & 0.133 & 0.148 & 0.195 & 0.059 & 0.079 & 0.061 & 0.077 & 0.152 & 0.144 & 0.077 & 0.144 \\
\hline \multicolumn{12}{|l|}{$Z$ site } \\
\hline $\mathrm{Al}^{3+}$ & 6.000 & 6.000 & 6.000 & 6.000 & 6.000 & 6.000 & 6.000 & 6.000 & 6.000 & 6.000 & 6.000 \\
\hline $\mathrm{Mg}^{2+}$ & 0.000 & 0.000 & 0.000 & 0.000 & 0.000 & 0.000 & 0.000 & 0.000 & 0.000 & 0.000 & 0.000 \\
\hline \multicolumn{12}{|l|}{ Y site } \\
\hline $\mathrm{Ti}^{4+}$ & 0.092 & 0.032 & 0.024 & 0.097 & 0.055 & 0.010 & 0.082 & 0.107 & 0.059 & 0.069 & 0.059 \\
\hline $\mathrm{Al}^{3+}$ & 0.481 & 0.797 & 0.704 & 0.517 & 0.708 & 0.821 & 0.418 & 0.563 & 0.672 & 0.692 & 0.672 \\
\hline $\mathrm{V}^{3+}$ & 0.006 & 0.002 & 0.000 & 0.002 & 0.000 & 0.001 & 0.002 & 0.005 & 0.000 & 0.000 & 0.000 \\
\hline $\mathrm{Fe}^{2+}$ & 1.716 & 1.465 & 1.952 & 0.997 & 1.692 & 1.937 & 1.660 & 1.769 & 1.567 & 1.663 & 1.567 \\
\hline $\mathrm{Mg}^{2+}$ & 0.600 & 0.556 & 0.262 & 1.236 & 0.395 & 0.103 & 0.713 & 0.401 & 0.529 & 0.370 & 0.529 \\
\hline $\mathrm{Mn}^{2+}$ & 0.024 & 0.015 & 0.034 & 0.005 & 0.019 & 0.026 & 0.022 & 0.020 & 0.021 & 0.021 & 0.021 \\
\hline $\mathrm{Zn}^{2+}$ & 0.000 & 0.000 & 0.000 & 0.000 & 0.000 & 0.000 & 0.009 & 0.008 & 0.000 & 0.000 & 0.000 \\
\hline \multicolumn{12}{|l|}{$\mathrm{X}$ site } \\
\hline $\mathrm{Ca}^{2+}$ & 0.031 & 0.017 & 0.035 & 0.047 & 0.026 & 0.018 & 0.052 & 0.048 & 0.034 & 0.030 & 0.034 \\
\hline $\mathrm{Na}^{+}$ & 0.544 & 0.501 & 0.409 & 0.537 & 0.457 & 0.380 & 0.569 & 0.517 & 0.578 & 0.546 & 0.578 \\
\hline $\mathrm{K}^{+}$ & 0.011 & 0.007 & 0.007 & 0.004 & 0.009 & 0.004 & 0.010 & 0.010 & 0.011 & 0.009 & 0.011 \\
\hline Vacancy & 0.414 & 0.476 & 0.550 & 0.413 & 0.508 & 0.597 & 0.368 & 0.425 & 0.377 & 0.415 & 0.377 \\
\hline $\mathrm{OH}$ & 3.692 & 3.856 & 3.859 & 3.966 & 3.876 & 3.942 & 3.808 & 3.921 & 3.868 & 3.813 & 3.868 \\
\hline $\mathrm{F}^{-}$ & 0.307 & 0.144 & 0.141 & 0.034 & 0.122 & 0.058 & 0.188 & 0.079 & 0.132 & 0.184 & 0.132 \\
\hline $\mathrm{Cl}^{-}$ & 0.000 & 0.000 & 0.000 & 0.000 & 0.000 & 0.000 & 0.000 & 0.000 & 0.000 & 0.000 & 0.000 \\
\hline $\mathrm{B}^{3+}$ & 3.000 & 3.000 & 3.000 & 3.000 & 3.000 & 3.000 & 3.000 & 3.000 & 3.000 & 3.000 & 3.000 \\
\hline
\end{tabular}

* calculated from stoichiometry, total $\mathrm{Fe}$ as $\mathrm{FeO}$

Rock types: tourmaline granites (TG), tourmaline nodules (TN), tourmaline pegmatites (TP)

are compositionally rather homogenous $(\mathrm{MnO}=2.0-2.4$ wt. $\%, \mathrm{FeO}=0.16-0.17$ wt. $\%, \mathrm{~F}=4.5-5.0$ wt. $\%$ ). Anhedral to subhedral grains of apatite II $(20-400 \mu \mathrm{m})$, often enclosed in tourmaline of the nodules, shows irregular zoning characterized by a depletion of $\mathrm{Fe}$ and $\mathrm{Mn}$ towards the crystal rims $(\mathrm{MnO}=1.21-2.09 \mathrm{wt}$. $\%, \mathrm{FeO}=0.03-0.16$ wt. $\%, \mathrm{~F}=4.8-5.6$ wt. $\%)$. The cores of apatite II crystals are $\mathrm{MnO}(2.32-3.59 \mathrm{wt} . \%)$ and $\mathrm{FeO}(0.22-0.84$ wt. \%) rich. Small $(10-40 \mu \mathrm{m})$, subhedral grains of $(\mathrm{Fe}, \mathrm{Mn})$-poor apatite III $(\mathrm{MnO}=$ $1.20-1.40$ wt. $\%, \mathrm{FeO}=0.00-0.10$ wt. $\%, \mathrm{~F}=5.3-5.6$ wt. \%) occur especially in TN and LH. They are irregularly distributed along intergranulars and in internal parts of plagioclase grains.

Monazite-(Ce) to rare cheralite-(Ce) associated with fluorapatite, zircon and xenotime in MBG occurs as small $(<30 \mu \mathrm{m})$ oval subhedral crystals with diffuse or irregular zoning. Chondrite-normalized (Boynton 1984) LREE patterns are mutually comparable $\left(\mathrm{La}_{\mathrm{N}} / \mathrm{Sm}_{\mathrm{N}}=3-5\right)$. Very small homogeneous monazite grains $(<15 \mu \mathrm{m})$ from tourmaline-bearing granite and TN are compositionally similar to those from the MBG. 

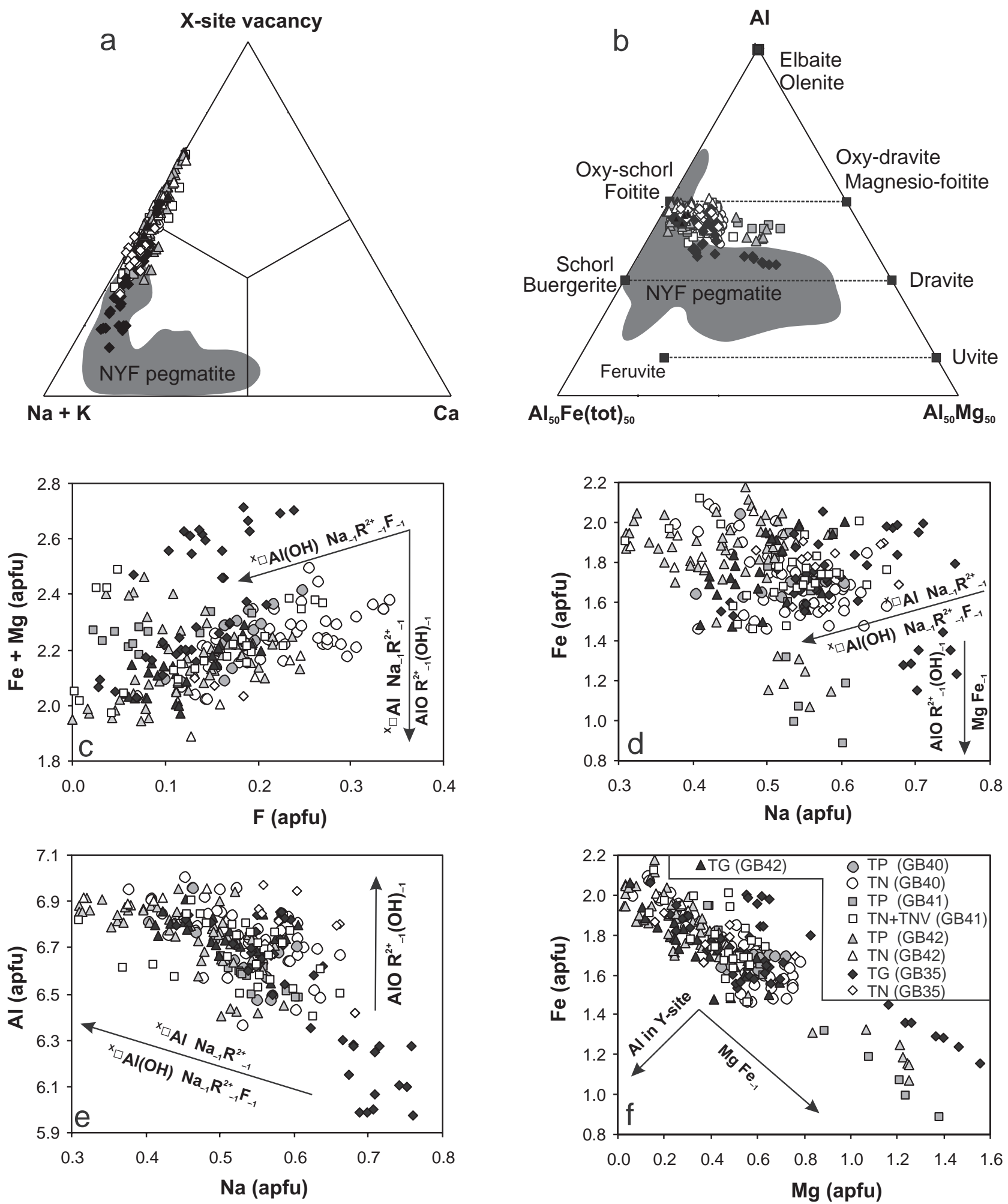

Fig. 9 Chemical composition of tourmaline from pegmatites, tourmaline granites and tourmaline nodules: $\mathbf{a}-\mathrm{Na}+\mathrm{K}-\mathrm{X}$-site vacancy $-\mathrm{Ca}$ triangle; $\mathbf{b}-\mathrm{Fe}_{\text {tot }}-\mathrm{Al}-\mathrm{Mg}$ triangle; $\mathbf{c}-\mathrm{F}$ vs. Fe $+\mathrm{Mg}$; d $-\mathrm{Na}$ vs. Fe; e $-\mathrm{Na}$ vs. Al; f $-\mathrm{Mg}$ vs. Fe. Chemical compositions of tourmalines from NYF pegmatites of the Třebíč Pluton are from Novák et al. (2011).

Xenotime-(Y) is present in all rock types mainly as inclusions in feldspars, tourmaline and, rarely, monazite. Euhedral, homogeneous or oscillatory-zoned grains of zircon $(\leq 80 \mu \mathrm{m})$, sporadically intergrown with monazite are common in MBG and tourmaline-bearing granite. Relatively rare, subhedral zircon commonly with sector 

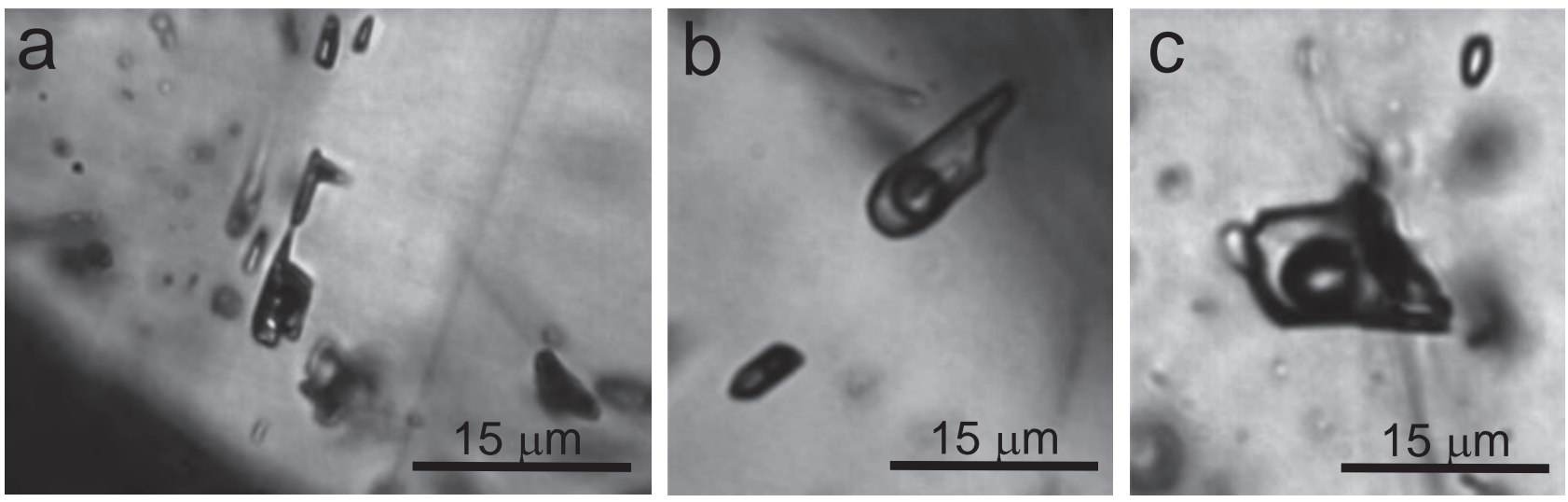

Fig. 10 Appearance of fluid inclusions: a - elongated primary fluid inclusions arranged along growth zones in tourmaline (tourmaline nodule GB42/N); b - primary two-phase $\mathrm{L}+\mathrm{V}$ inclusions hosted by tourmaline (tourmaline nodule GB42/N); c - two-phase L $+\mathrm{V}$ primary inclusion hosted by quartz (pegmatite GB42/P). In the upright corner also one secondary L-only inclusion is present.

zoning and locally overgrowing small xenotime nuclei occurs in TN. Unaltered zircon grains from all rock types have relatively uniform $\mathrm{Hf}$ contents $\left(\mathrm{HfO}_{2}=1.0-2.4\right.$ wt. \%). Elevated contents of $\mathrm{P}$ and $\mathrm{Th}$ in some grains are related to late hydrothermal alterations.

Ilmenite to pyrophanite $\left(\mathrm{Ilm}_{100-11}, \mathrm{Pyr}_{89-0}\right)$ is a typical accessory mineral in all rock types. It is most abundant in the MBG, where it forms euhedral to subhedral laths, locally with rutile inclusions. Rare ilmenite from the nodules is partly replaced by rutile.

\subsection{Fluid inclusions}

Fluid inclusions (Fig. 10) trapped in quartz and tourmaline were studied in three samples; one from the central part of a pegmatite dyke composed of quartz and tourmaline (GB42E), and two from tourmaline nodules (TN) (GB41B and GB42N). Primary (P), pseudosecondary (PS) and secondary (S) inclusions were found in tourmaline from all samples.

In tourmaline, primary inclusions are related to growth zones, forming three-dimensional clusters or being isolated. Quartz-hosted primary inclusions occur only in clusters or as isolated ones. The inclusions $(4-18 \mu \mathrm{m}$ in size) typically have isometric three-dimensional morphology without any tips (in quartz); locally elongated forms are arranged parallel to the $c$-axis of the host crystal (in tourmaline). All primary inclusions are aqueous, showing $\mathrm{L}+\mathrm{V}$ phase compositions with essentially stable phase proportions in the individual inclusions (20-30 vol. \% of the vapor phase). The PS and S inclusions are concentrated along healed fractures. The PS inclusions have the same phase composition as primary inclusions, whereas secondary ones involve both $\mathrm{L}$ and $\mathrm{L}+\mathrm{V}$ types, randomly distributed within a single trail. In addition, the $\mathrm{L}+\mathrm{V}$ secondary inclusions exhibit a wide variability in liquid-vapor ratios (5-20 vol. \% vapor). Secondary inclusions were large enough for conventional micro- thermometric analysis (i.e., $>5 \mu \mathrm{m}$ ) only in quartz from tourmaline pegmatites.

The microthermometric measurements are summarized in Tab. 6 and Fig. 11a-c. Primary and pseudosecondary inclusions display always very similar ranges of microthermometric parameters. The homogenization temperatures of P-PS inclusions range between 208 and $398^{\circ} \mathrm{C}$ showing the highest probability density range from 250 to $350^{\circ} \mathrm{C}$ (Fig. 11a). The P-PS inclusions freeze at temperatures between -31 and $-52{ }^{\circ} \mathrm{C}$, and remain colorless. Though rarely observed, initial melting occurs between -32 and $-40^{\circ} \mathrm{C}$. Melting of ice takes place between -0.1 and $-9.4^{\circ} \mathrm{C}$ (Fig. 11b). In P-PS inclusions from pegmatites with tourmaline melting of clathrate is also observed between +5.0 and $+13.4^{\circ} \mathrm{C}$ (Fig. 11c), whereas the inclusions from TN lack clathrate except for one inclusion of problematic genetic ranking which showed Tm-cla as high as $+15.2^{\circ} \mathrm{C}$ (Tab. 6, Fig. 11c). Raman analysis of vapor bubbles in clathrateforming inclusions yielded methane (peak at $\sim 2917 \mathrm{~cm}^{-1}$ ) as the only detectable gas compound.

Secondary $\mathrm{L}+\mathrm{V}$ inclusions in quartz from pegmatites with tourmaline exhibit mostly lower homogenization temperatures $\left(162-234^{\circ} \mathrm{C}\right)$ and higher Tm-ice $(-0.2$ to $-2.3^{\circ} \mathrm{C}$ ) than the primary ones. The secondary L-only inclusions show similar Te and Tm-ice values as the associated $\mathrm{L}+\mathrm{V}$ inclusions pointing to probable metastability of their phase composition.

\section{Discussion}

\subsection{P-T conditions of crystallization}

The examined granitic system crystalized likely in the succession tourmaline-free muscovite-biotite granite $\rightarrow$ tourmaline-bearing granite $\rightarrow$ pegmatites with tourmaline $\rightarrow$ tourmaline nodules (and TNV) + leucocratic halos $\rightarrow$ quartz-tourmaline veins (see Fig. 2d-g; 12a) and repre- 
Tab. 6 Results of microthermometric measurements of fluid inclusions

\begin{tabular}{|c|c|c|c|c|c|c|c|c|c|}
\hline Sample & Rock & Mineral & FI type & Phase composition & Th-tot & $\mathrm{Tf}$ & $\mathrm{Te}$ & Tm ice & Tm cla \\
\hline \multirow[t]{3}{*}{ GB42/P } & Pegmatite & Tourmaline & P, PS & $\mathrm{L}+\mathrm{V}$ & $251-377$ & $-35 /-46$ & -33 & $-1.6 /-4.2$ & $+9.3 /+13.4$ \\
\hline & & Quartz & P, PS & $\mathrm{L}+\mathrm{V}$ & $265-333$ & $-31 /-44$ & $-37 /-38$ & $-3.1 /-9.4$ & $+5.0 /+11.1$ \\
\hline & & & $\mathrm{S}$ & $\mathrm{L}, \mathrm{L}+\mathrm{V}$ & $162-234$ & $-31 /-43$ & n.d. & $-0.2 /-2.3$ & n.a. \\
\hline \multirow[t]{2}{*}{$\mathrm{GB} 42 / \mathrm{N}$} & Tur nodule & Tourmaline & P, PS & $\mathrm{L}+\mathrm{V}$ & $250-382$ & $-42 /-46$ & -36 & $-1.3 /-4.0$ & n.a. \\
\hline & & Quartz & $\mathrm{P}, \mathrm{PS}$ & $\mathrm{L}+\mathrm{V}$ & $303-393$ & $-34 /-49$ & -37 & $-0.1 /-5.3$ & n.a. \\
\hline \multirow[t]{2}{*}{$\mathrm{GB} 41 / \mathrm{G}$} & Tur nodule & Tourmaline & $\mathrm{P}, \mathrm{PS}$ & $\mathrm{L}+\mathrm{V}$ & $248-365$ & $-36 /-45$ & -32 & $-1.2 /-4.2$ & n.a. \\
\hline & & & $?$ & $\mathrm{~L}+\mathrm{V}$ & $317(d)$ & -47 & -40 & -1.8 & 15,2 \\
\hline
\end{tabular}

Temperature parameters are given in ${ }^{\circ} \mathrm{C}$

(d) - decrepitation temperature

n.a. - does not contain clathrate-forming gas

n.d. - not determined

sents a typical example of evolution from magmatic to hydrothermal stage (e.g. Pichavant and Manning 1984; Trumbull et al. 2008). Granophyric and comb textures in the border zone of the MBG near the contact with surrounding durbachites (Fig. $2 \mathrm{~g}$ ) indicate rapid crystallization of an undercooled granitic melt at a shallow crustal level (e.g., Barker 1970; London et al. 1996; Morgan and London 1999; Webber et al. 1999). The emplacement conditions of $\mathrm{MBG}$ have been estimated at c. $670-740^{\circ} \mathrm{C}$ and $0.1-0.4 \mathrm{GPa}$ using the zircon and monazite saturation thermometry (Watson and Harrison 1983; Montel 1993) and considering that the magma was emplaced within the andalusite stability field (Clarke et al. 2005). But the lower pressure is likely because the emplacement pressure of the host durbachite was estimated at 0.2-0.4 GPa (Novák and Houzar 1996; Leichmann et al. 2017). The calculated monazite and zircon saturation temperatures close to the solidus of peraluminous melts $\left(\sim 700^{\circ} \mathrm{C}\right.$ for $\mathrm{P} \sim 0.2 \mathrm{GPa}$; Huang and Wyllie 1981) also suggest $\sim 0.2$ $\mathrm{GPa}$ for the MBG crystallization.

Tectonic deformation during late stages of primary crystallization was responsible for fracturing of MBG and formation of thin dykes of tourmaline-bearing granite. A slightly lower crystallization temperature of tourmalinebearing granite relative to $\mathrm{MBG}$ (zircon and monazite saturation thermometry: c. $640-700^{\circ} \mathrm{C}$ ) is in agreement. Such temperatures are consistent with lower solidus temperatures of fluid-saturated B-rich granitic melts (Pichavant 1981; Pichavant and Manning 1984; Spicer et al. 2004).

Similarly to the tourmaline granites, pegmatite dykes cutting the MBG near its contact with durbachites (Fig. 2g, 12b) crystallized from residual melts derived from the host MBG. The elevated phosphorus contents in feldspar (Fig. 8a) and $\mathrm{X}_{\mathrm{Fe}}$ in biotite (0.81-0.91) from pegmatite dykes higher than in biotite from the marginal part of MBG $\left(\mathrm{X}_{\mathrm{Fe}}=0.69-0.75\right)$ suggest the higher degree of fractionation of the pegmatites with tourmaline (see also Villaseca and Barbero 1994).

The isochores of primary and primary-secondary aqueous inclusions from pegmatites with tourmaline and tourmaline nodules are similar (Fig. 12b). Fluid inclusions in tourmaline and quartz from the central parts of the tourmaline-bearing pegmatite dykes were trapped below the magmatic-hydrothermal transition at c. $400-550{ }^{\circ} \mathrm{C}$ and $0.2 \mathrm{GPa}$; tourmaline from the $\mathrm{TN}$ crystallized at similar conditions with a slightly wider temperature range $\left(400-640^{\circ} \mathrm{C}\right.$; Fig. $\left.12 \mathrm{~b}\right)$. These $\mathrm{P}-\mathrm{T}$ conditions are characteristic of the late-stage solidus crystallization of granitic pegmatites (London 1986; Morgan and London 1999; London 2008; Nabelek et al. 2009).

\subsection{Nature and origin of the fluid phase hosted by fluid inclusions}

The nodule-hosted P and PS fluid inclusions exhibit mutually well comparable microthermometric parameters in quartz and tourmaline from different samples. They do not contain an elevated content of clathrate-forming gas. The initial melting temperatures are consistent with the presence of divalent-metal (i.e. $\mathrm{Mg}, \mathrm{Fe}$ ) chlorides in addition to $\mathrm{NaCl}$ with the fluid salinities $0.2-8.3$ wt. \% $\mathrm{NaCl}$ eq. (Bodnar 1993).

The pegmatite-hosted fluid inclusions seem to contain an analogous salt system (similar Tf and Te) but presence of an elevated content of methane (Raman analysis). Based on modelling in the ICE software (Bakker 1997), the microthermometric data are compatible with 92.494.8 mol. \% $\mathrm{H}_{2} \mathrm{O}, 2.1-5.2 \mathrm{~mol}$ \% $\mathrm{CH}_{4}, 2.2-3.1 \mathrm{~mol}$ \% $\mathrm{NaCl}$ and the salinity of the aqueous solution 4.1-5.0 wt. $\% \mathrm{NaCl}$. The given ranges include also the data with very low Tm-ice values; the effect of lower Tm-ice value is compensated by a higher amount of methane pointing to a negative correlation of both variables. The bulk molar volumes of the fluid phase are 21.72 and $24.99 \mathrm{~cm}^{3} / \mathrm{mol}$ (BULK software; Bakker 2003).

The composition and densities of TN-hosted fluid inclusions seem to be consistent with a fluid phase exsolved from the crystallizing magma. The subhorizontal trend in the Th-Tm diagram (Fig. 11d) is compatible with 

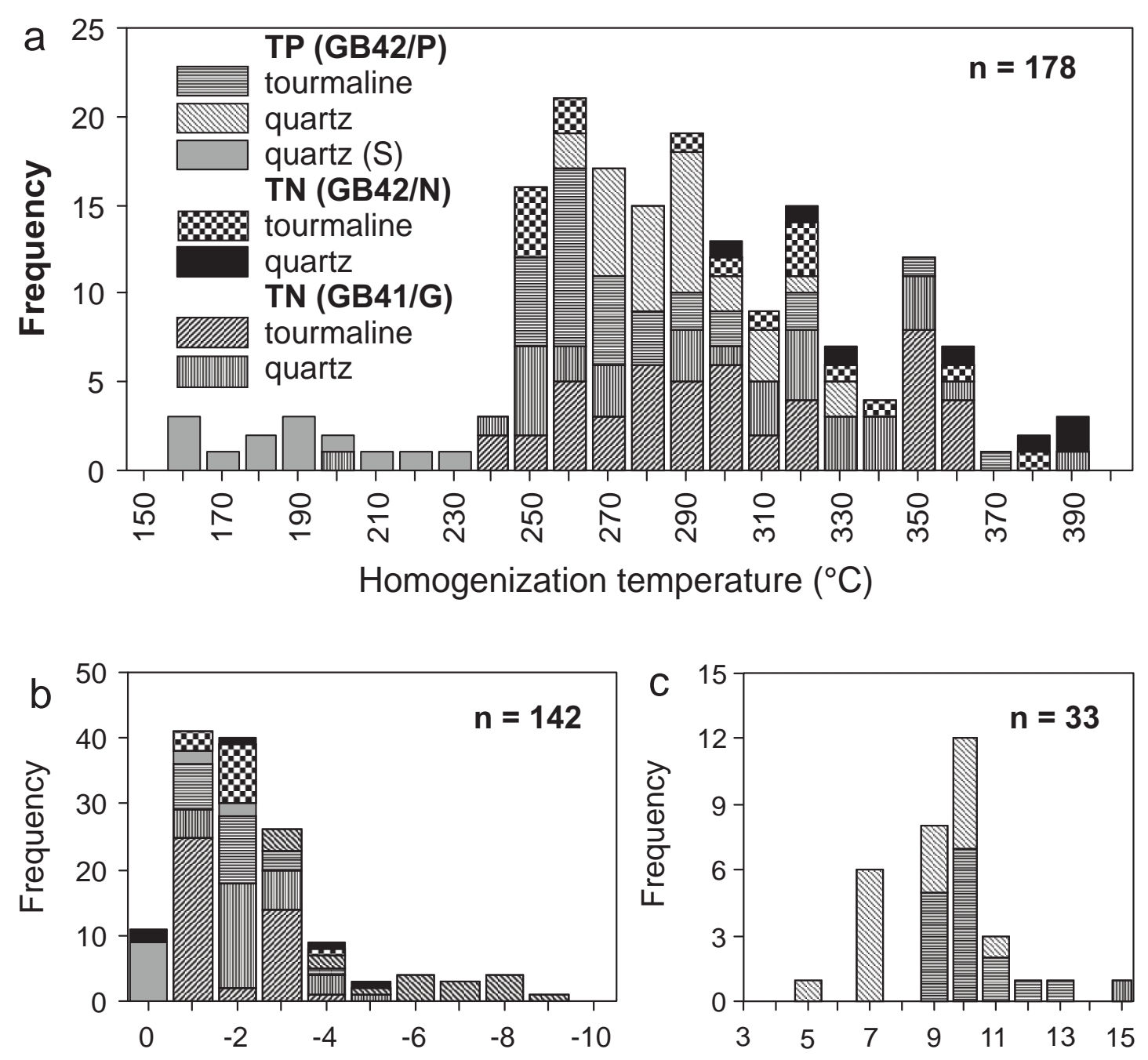

Ice melting temperature $\left({ }^{\circ} \mathrm{C}\right)$

Clathrate melting temperature $\left({ }^{\circ} \mathrm{C}\right)$

Homogenization temperature $\left({ }^{\circ} \mathrm{C}\right)$

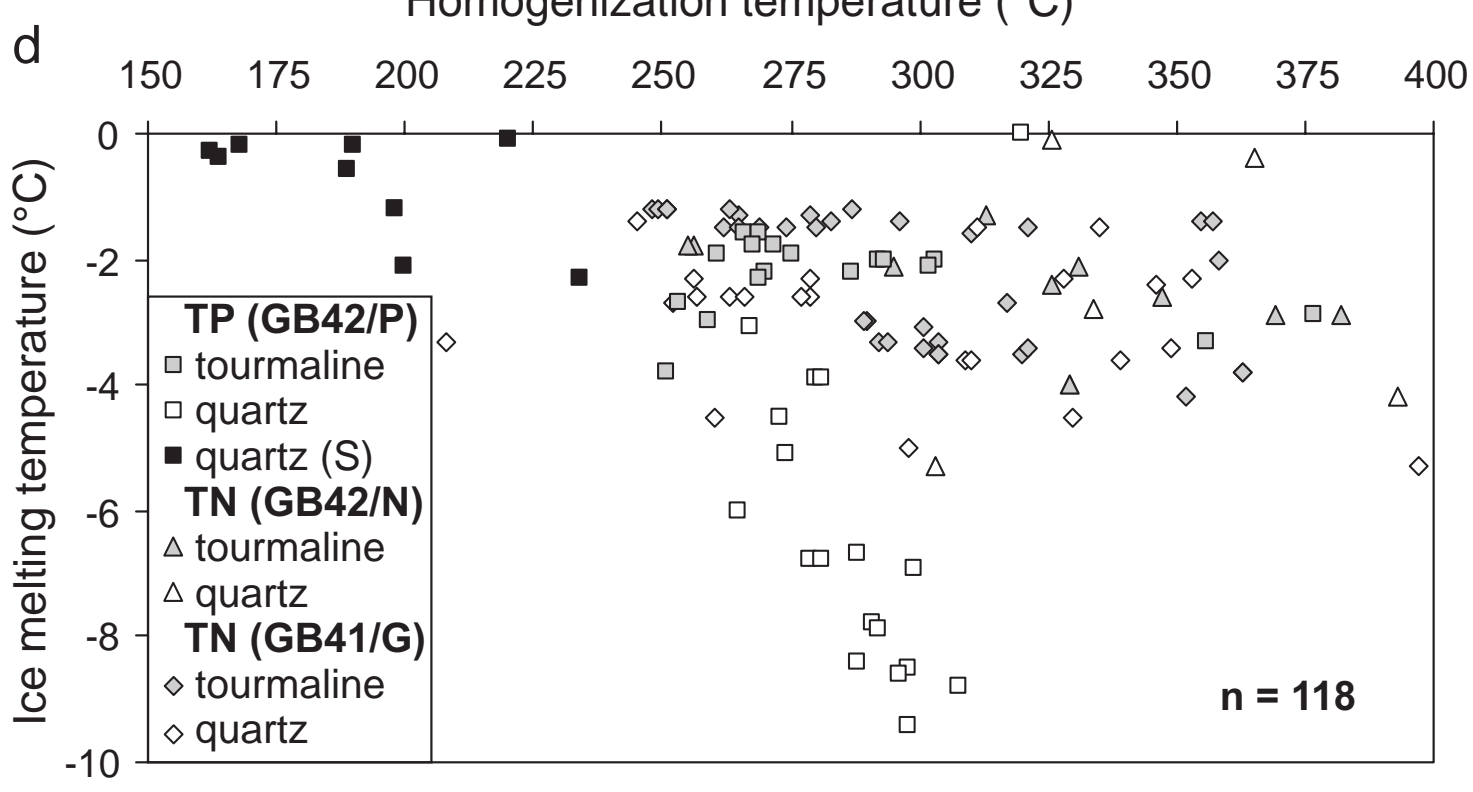



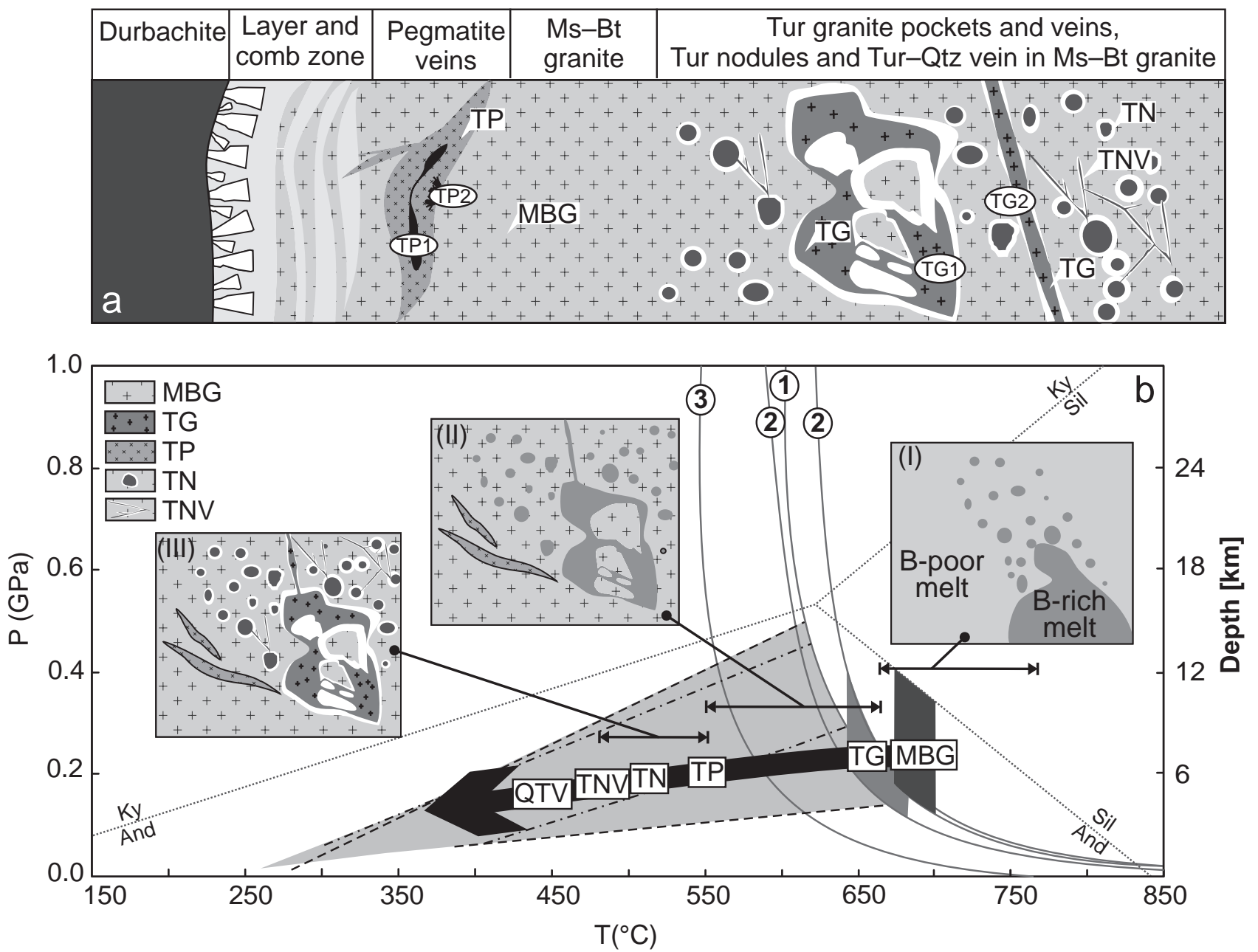

Fig. 12a - Schematic cross-section across the studied granite dyke showing the relations among muscovite-biotite granites (MBG), tourmaline granites (TG), tourmaline pegmatites (TP), tourmaline nodules (TN) and quartz-tourmaline veins (QTV, TNV). b - An evolutionary diagram summarizing the relevant information pertaining to the P-T history of granite system and featuring: I - immiscibility between B-rich hydrous and peraluminous granite melts, II - exsolution of the pegmatite melt, III - formation of the leucocratic halos. Crystallization temperatures for MBG and TG were assessed by the zircon and monazite saturation temperatures. Pressures were estimated according to the emplacement conditions of the host durbachite (Leichmann et al. 2017), the maximum andalusite stability (Richardson et al. 1969) and experimental data as follows. $1-\mathrm{H}_{2} \mathrm{O}-$ and Al-saturated granite solidus (Tuttle and Bowen 1958); 2 - range between wet granite solidus and wet granite solidus where $\mathrm{B}_{2} \mathrm{O}_{3}$ concentration in the melt is buffered by equilibria involving tourmaline; 3 - maximum shift of the haplogranitic wet solidus resulting from the addition of up to 17 wt. $\% \mathrm{~B}_{2} \mathrm{O}_{3}$ (Spicer et al. 2004). The grey field covers the area of the estimated P-T conditions defined by isochores of P and PS fluid inclusions hosted by both quartz and tourmaline. Representative isochores for both pegmatite-hosted $\mathrm{CH}_{4}$-bearing fluid inclusions (dashed lines) and nodulehosted $\mathrm{CH}_{4}$-absent fluid inclusions (dot-and-dash lines) are also shown.

(i) simple cooling of a high-temperature fluid, (ii) decrease in pressure or (iii) combination of both options (e.g. Cline and Bodnar 1991). However, the first option is the most probable considering the textural and paragenetic evolution of the host tourmaline.

In the absence of redox reactions involving carbon species (e.g. precipitation of graphite), the presence ↔

Fig. 11 Graphical presentation of microthermometric data for fluid inclusions hosted by quartz and tourmaline: $\mathbf{a}$ - histogram of the homogenization temperature values; $\mathbf{b}$ - histogram of the melting temperatures of ice; $\mathbf{c}$ - histogram of melting temperatures of clathrate; d - homogenization temperature vs. ice melting temperature plot. of methane only in tourmaline pegmatites-hosted fluid inclusions is possibly explained by partial infiltration of an external fluid phase (Thomas and Spooner 1988) from the surrounding rocks of the Třebíc Pluton or from its metasedimentary envelope. Many studies demonstrated that even the high-T fluids operating in a magmatic environment can be derived from external sources (e.g. Banks et al. 2000; Polya et al. 2000; Dolníček et al. 2012). The opening of the pegmatite system to external fluids is not surprising because the diagonal distribution of quartz-hosted fluid inclusion data in the Th-Tm plot (Fig. 11d) which clearly points to mixing of two fluids with contrasting $\mathrm{T}-\mathrm{X}$ characteristics. The presence of 
dravite-rich rims (Fig. 9 b, d, f) in tourmaline from the central part of tourmaline pegmatites dykes may suggest an input of Mg-rich external fluids. This was also documented in tourmaline from similar nodular granites at Lavičky (Buriánek and Novák 2004) and from some granitic pegmatites in the Moldanubicum (e.g., Novák et al. 1999, 2011; Gadas et al. 2012).

\subsection{Evolution of granitic melts and saturation of tourmaline}

Tourmaline is a good indicator for the evolution of granite melts (e.g. London and Manning 1995; Wolf and London 1997; London 1999; Dutrow and Henry 2011; van Hinsberg et al. 2011). The important factors controlling tourmaline stability in granitic melts at $700-750{ }^{\circ} \mathrm{C}$ are sufficiently high contents of $\mathrm{B}$ (more than 2 wt. $\% \mathrm{~B}_{2} \mathrm{O}_{3}$ ), $\mathrm{Fe}$ and/or $\mathrm{Mg}$, along with high $\mathrm{Al}(\mathrm{A} / \mathrm{CNK}>1.2)$ (Benard et al. 1985; London and Manning 1995; Scaillet et al. 1995; Wolf and London 1997; Spicer et al. 2004; London 2011). Still, high $\mathrm{Fe}^{3+}$ content may stabilize tourmaline in alkaline conditions (Filip et al. 2012). In contrast, saturation of tourmaline from hydrothermal fluids requires less than 0.1 wt. $\% \mathrm{~B}_{2} \mathrm{O}_{3}$ (London 2011).

During the crystallization of granite melts, B-rich residual melts are often generated (e.g., London et al. 1996; Thomas et al. 2003). They are progressively enriched in water, B, F and other incompatible or volatile elements, leading to a strong reduction of melt viscosity (e.g. Pichavant 1981; Pichavant et al. 1987; Holtz and Johannes 1991; Dingwell et al. 1996; London 1999; Thomas and Webster 2000). Experimental studies on volatile-rich granite pegmatites (Veksler and Thomas 2002; Veksler et al. 2002) and on B-rich inclusions in pegmatites (Thomas et al. 2003) show that hydrous B-rich melts/fluids are immiscible in peraluminous melts. Granitic rocks and associated tourmaline in the Třebíč Pluton discussed below illustrate variability of these processes including several stages of tourmaline saturation from magmatic to hydrothermal stage (Figs 12-13).

\subsubsection{Muscovite-biotite granite and tourmaline nodules with the surrounding leucocratic halos}

The granophyric and comb textures in the marginal part of the MBG dyke suggest undercooling (Baker and Freda 1999; Webber and Simmons 2007; Nabelek et al. 2009). The central part of the dyke generally exhibits a regular medium-grained granitic texture, an absence of disseminated tourmaline and a low amount of muscovite, which are consistent with low $\mathrm{B}$ contents and low to moderate peraluminosity ( $\mathrm{A} / \mathrm{CNK}=1.07$ to 1.20$)$. Granitic textures and mineral assemblages indicate crystallization from fluid-undersaturated melt (London 1999).

Boron-rich melt has a lower solidus temperature than a B-poor peraluminous one (e.g. Pichavant 1981; Pichavant et al. 1987; Holtz and Johannes 1991) which is in agreement with the monazite and zircon saturation temperatures that are lower for the tourmaline-bearing granite than for the host MBG. The tourmaline nodules with leucocratic halos within MBG (Fig. 2a) represent further episode of the granite evolution and the abundant concentration of tourmaline manifests that the granitic melt reached B contents high enough to precipitate tourmaline (London and Manning 1995; London 1999).
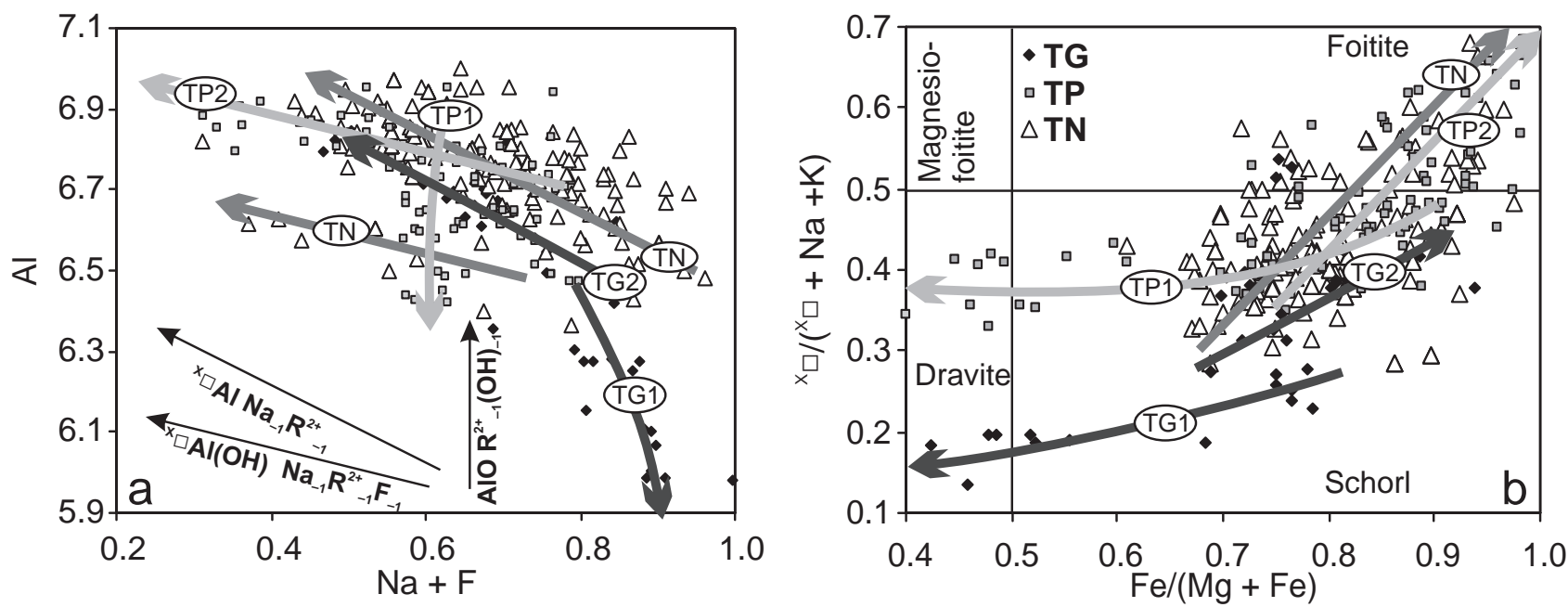

Fig. 13 Chemical composition of tourmaline from pegmatites (TP), tourmaline granites (TG) and tourmaline nodules (TN) (apfu): a $-\mathrm{Na}+\mathrm{F}$ vs. $\mathrm{Al} ; \mathbf{b}-\mathrm{Fe} /(\mathrm{Mg}+\mathrm{Fe})$ vs. ${ }^{\mathrm{X}_{\square}} /\left(\mathrm{X}_{\square}+\mathrm{Na}+\mathrm{K}\right)$. Based on the tourmaline chemical zoning, five evolution trends can be distinguished, shown by arrows: TG1 - patchy-zoned tourmaline core from the granite, TG2 - rim of tourmaline crystals from the granite, TP1 - rim of tourmaline in the miarolitic cavities from pegmatite veins, TP2 - tourmaline with comb textures from pegmatites, TN - tourmaline from nodules. 
Textural and compositional features of tourmalinebearing nodules allow two possible explanations of their origin: crystallization from B-rich aqueous fluids (e.g. Sinclair and Richardson 1992; Rozendaal and Bruwer 1995; Kubiš and Broska 2005, 2010; Balen and Broska 2011) or crystallization from B-rich residual melt (Němec 1975; Buriánek 2003; Barbey 2007; Balen and Petrinec 2011). It is difficult to explain the spatial segregation of tourmaline-rich nodules by exsolved aqueous fluids because they can hardly accumulate such high concentrations of $\mathrm{Fe}$ and/or $\mathrm{Mg}$ from internal sources, i.e. from the surrounding granite (Němec 1975; Barbey 2007; Trumbull et al. 2008). Instead, mass-balance calculations for TN and surrounding MBG (Fig. 7) indicate that the $(\mathrm{Fe}, \mathrm{Mg})$-enrichment can be achieved only by scavenging the ferromagnesian elements from the adjacent granite, resulting in the formation of the leucocratic halos (Němec 1975; Buriánek 2003; Barbey 2007; Balen and Petrinec 2011).

Indeed, the water-rich, depolymerized melt can be strongly enriched in $\mathrm{B}, \mathrm{Fe}$ and $\mathrm{Al}$ (Thomas et al. 2003; Veksler 2004). Moreover, high contents of $\mathrm{Cl}$ in fluid inclusions (TN) may stabilize B in the melt (Sinclair and Richardson 1992; Swanson and Fenn 1992; Schatz et al. 2004). Crystallization from a B-rich melt is also indicated by the radially growing tourmaline crystals from the center of the nodule toward the leucocratic halo. This morphology is associated with melt crystallization at undercooled conditions (Perugini and Poli 2007; Longfellow and Swanson 2009) whereas small miarolitic cavities found in some nodules (Fig. 2f) are typical of the magmatic to hydrothermal transition at shallow depths (Sinclair and Richardson 1992; Touret et al 2007). It seems that the tourmaline granites were products of crystallization from a B-rich melt; however, final stage of their formation may have been related with the segregation of a B-rich fluid phase, responsible for the origin of the LH. The oval shape of TN (Fig. 2a, c-f) may be a product of immiscibility of a B-poor melt and a B-rich residual melt/fluid. The textural evolution from bubble-shaped nodules to TNV (see also Buriánek and Novák 2004) indicates their origin across a rheological transition of the host from deformable magma to brittle, almost solid granite (MBG). The mineral assemblages possibly also recorded the transition between magmatic and hydrothermal stages (e.g. Trumbull et al. 2008).

Fluid inclusions in the external parts of tourmaline grains suggest crystallization from hydrothermal fluids indicated also by low $\mathrm{K} / \mathrm{Rb}$ ratios $(54-155)$ of the $\mathrm{TN}$. The distinct $\mathrm{P}$ contents found in TN and LH mimic irregular distribution of apatite III as a product of hydrothermal alteration of feldspars.

The main difference between nodules and the surrounding haloes is the absence of tourmaline in the lat- ter. The halos have modal composition similar to MBG except for the absence of biotite. The chemical zoning of plagioclases is comparable as are the chemical and oxygen isotope compositions $\left(\delta^{18} \mathrm{O}=+7.7\right.$ and $\left.+7.1 \%\right)$. Small differences still exist in the LILE contents as a consequence of the variation in feldspars abundances.

The formation of the halos could be explained by the reaction of MBG with magmatic fluids exsolved from Brich melt in bubbles and veins (TN, TNV and tourmalinebearing granite). Biotite breakdown is considered the source of $\mathrm{Fe}$ and $\mathrm{Mg}$ for the formation of tourmaline (Fig. $13 \mathrm{a}-\mathrm{b})$ during late stages of boron-rich nodules' crystallization (Němec 1975). This process requires diffusion of ferromagnesian components toward TN indicated by decreased contents of some elements (Ti, Fe, Mg, Sc, $\mathrm{Ga}$ ) preferentially incorporated in biotite (Neves 1997) in the leucocratic nodules as compared with the MBG and TN (Fig. 6).

\subsubsection{Intrusive tourmaline-bearing rocks cutting the host MBG - tourmaline granite and tourmaline pegmatite}

Tourmaline granite in veins has sharp contacts with the surrounding MBG and LH. The lower REE, Th, Ba and Sr contents compared to MBG correspond to a more evolved granite melt. During the magmatic differentiation of peraluminous granites, both LREE contents and $\mathrm{Th} / \mathrm{U}$ ratios drop as the result of monazite fractionation (Maruéjol et al. 1990). According to the textural relationships (i.e., the presence of LH), tourmaline-bearing granite crystallized simultaneously with the TN and TNV (Fig. 12). However, tourmaline-bearing granite reached the solidus earlier, probably due to loss of fluid phase during intrusion to the joints. On the contrary, the fluid phase was in the TN preserved forming a closed system and finally interacted with the surrounding MBG and produced the leucocratic halos.

Small irregular bodies and dykes of pegmatites with tourmaline (Fig. 13a-b) represent the last magmatic event in the evolution of these granitic rocks. They are developed mainly near the contact of MBG with surrounding rocks (durbachite) as dykes subparallel with the contact plane.

\subsubsection{Hydrothermal tourmaline}

The latest saturation of B is represented by several textural and paragenetic types of hydrothermal tourmaline: (i) thin quartz + tourmaline veinlets cutting the early tourmaline grains (Fig. 2g-h), (ii) late quartz veins with fibrous dravite, up to several $\mathrm{m}$ long, cutting MBG and (iii) dravite-rich rims and zones of tourmaline grains (see also Novák et al. 1997; Buriánek and Novák 2004). Chemical compositions of the outer zones of tourmaline crystals in granite and from the 
miarolitic cavities in pegmatites show compositional trend with dominant dravite (1) and ${ }^{\mathrm{Y}} \mathrm{R}^{2+\mathrm{w}} \mathrm{OH}^{\mathrm{Y}} \mathrm{Al}_{-1}{ }^{\mathrm{W}} \mathrm{O}_{-1}$ (4) substitutions (Fig. 13a-b). Crystallization of these tourmalines from a hydrothermal fluid in open system is indicated by the presence of methane in the fluid inclusions and the elevated $\mathrm{Mg}$ contents in tourmaline.

\section{Conclusions}

Crystallization of granite melts in the Třebíc Pluton produced several textural types of granitic rocks. The comb textures developed in other parts of muscovite-biotite granite (MBG) and in minor tourmaline pegmatite suggest a high degree of undercooling, whereas tourmaline granite has equigranular texture. Polyphase saturation of tourmaline produced the following textural and compositional types: (i) tourmaline nodules, each surrounded by a leucocratic halo, within MBG; (ii) euhedral to subhedral grains of tourmaline randomly distributed in tourmaline granite and tourmaline-quartz accumulations resembling the nodules with leucocratic halos, found in the marginal part of the tourmaline granite; (iii) rare columnar schorl crystals occurring locally in inner parts of tourmaline pegmatite; (iv) dravite-rich rims of tourmaline grains in tourmaline granite and pegmatite, as well as late dravite veinlets in tourmaline crystallized from hydrothermal fluids in a system open to host rocks.

These distinct textural and compositional types of tourmaline from granitic rocks of the Třebíč Pluton suggest that, during complex evolution of granitic melts, concentrations of B high enough to saturate tourmaline may have been achieved several times, at solidus and in subsolidus conditions.

Acknowledgements. The authors thank Pierre Barbey, Enrique Merino Martínez and an anonymous reviewer for constructive criticism that significantly improved the manuscript. They are also grateful to V. Mašek (LF UP) for Raman analysis of fluid inclusions. This work was supported by the research project GAČR P210/14/1347S to DB and MN and CGS research project No. 321180 to DB. The fluid inclusion study was financed by projects IGA UP PrF/2011/010 and PrF/2015/014 to ZD.

\section{References}

BAČík P, Cempírek J, Uher P, NovÁK M, Ozdín D, Filip J, Šmoda R, Breiter K, Klementová M, Duda R, Groat LA (2013) Oxy-schorl, $\mathrm{Na}\left(\mathrm{Fe}_{2}{ }^{2+}, \mathrm{Al}\right) \mathrm{Al}_{6} \mathrm{Si}_{6} \mathrm{O}_{18}\left(\mathrm{BO}_{3}\right)_{3}(\mathrm{OH})_{3} \mathrm{O}$, a new mineral from Zlatá Idka, Slovak Republic and Přibyslavice, Czech Republic. Amer Miner 98: 485-492 BAKER DR, FrEDA C (1999) Ising models of undercooled binary system crystallization: comparison with experimental and pegmatite textures. Amer Miner 84: 725-732

BAKKER RJ (1997) Clathrates: computer programs to calculate fluid inclusion $\mathrm{V}-\mathrm{X}$ properties using clathrate melting temperatures. Comput Geosci 23: 1-18

BAKker RJ (2003) Package FLUIDS 1. New computer programs for the analysis of fluid inclusion data and for modeling bulk fluid properties. Chem Geol 194: 3-23

Balen D, Broska I (2011) Tourmaline nodules: products of devolatilization within the final evolutionary stage of granitic melt? In: Sial AN, Bettencourt JS, De CAmpos CP, FerreiraVP (eds) Granite-Related Ore Deposits. Geological Society of London Special Publications 350: 53-68

Balen D, Petrinec Z (2011) Contrasting tourmaline types from peraluminous granites: a case study from Moslavacka Gora (Croatia). Mineral Petrol 102: 117-134

Banks DA, Green R, Cliff RA, Yardley BWD (2000) Chlorine isotopes in fluid inclusions: determination of the origins of salinity in magmatic fluids. Geochim Cosmochim Acta 64: 1785-1789

BARBEY P (2007) Diffusion-controlled biotite breakdown reaction textures at the solid/liquid transition in the continental crust. Contrib Mineral Petrol 154: 707-716

BARKER DS (1970) Compositions of granophyre, myrmekite, and graphic granite. Geol Soc Am Bull 81: 3339-3350

Benard F, Moutou P, Pichavant M (1985) Phase relations of tourmaline leucogranites and the significance of tourmaline in silicic magmas. J Geol 93: 1-29

BODNAR RJ (1993) Revised equation and table for determining the freezing point depression of $\mathrm{H}_{2} \mathrm{O}-\mathrm{NaCl}$ solutions. Geochim Cosmochim Acta 57: 683-684

Boynton WV (1984) Cosmochemistry of the rare earth elements: meteorite studies. In: HENDERSON PE (ed) Rare Earth Element Geochemistry. Elsevier, Amsterdam, pp 63-114

Breiter K (2010) Geochemical classification of Variscan granitoids in the Moldanubicum (Czech Republic, Austria). Abh Geol B -A 65: 19-25

BROwN PE (1989) FLINCOR: a microcomputer program for the reduction and investigation of fluid-inclusion data. Amer Miner 74: 1390-1393

BuBENíčEK J (1968) Geology and petrography of the Třebíč Massif. Sbor geol Věd, Geol 13: 133-164 (in Czech with English summary)

BuriánEK D (2003) Tourmaline granites from the Moldanubicum and Saxothuringicum - an example of using tourmaline as petrogenetic indicator. Unpublished $\mathrm{PhD}$ Thesis, Masaryk University, Brno, pp 1-256 (in Czech with English summary)

BuriáneK D, NovÁK M (2003) Tourmaline orbicules in leucogranites as indicator of geochemical fractionation of late solidus to early subsolidus magmatic fluids. J Czech Geol Soc 48: 30 
Buriánek D, NovÁk M (2004) Morphological and compositional evolution of tourmaline from nodular granite at Lavičky near Velké Meziříčí, Moldanubicum, Czech Republic. J Czech Geol Soc 49: 81-90

BuriáneK D, NovÁk M (2007) Compositional evolution and substitutions in disseminated and nodular tourmaline from leucocratic granites: examples from the Bohemian Massif, Czech Republic. Lithos 95: 148-164

Clarke DB, Dorais M, Barbarin B, Barker DAN, Cesare B, Clarke G, El Baghdadi M, Erdmann S, Forster HJ, Gaeta M, Gottesmann B, Jamieson RA, Kontak DJ, Koller F, Leal Gomes C, London D, Morgan GBV, Neves, LJPF, Pattison DRM, Pereira AJSC, Pichavant M, Rapela CW, Renno AD, Richards S, Roberts M, Rottura A, SaAvedra J, Sial AN, Toselli AJ, Ugidos JM, Uher P, Villaseca C, Visona D, Whitney DL, Williamson BEN, Woodard HH (2005) Occurrence and origin of andalusite in peraluminous felsic igneous rocks. J Petrol 46: 441-472

Clayton RN, Mayeda T (1963) The use of bromine pentafluoride in the extraction of oxygen from oxides and silicates for isotopic analysis. Geochim Cosmochim Acta 27: 47-52

Cline JS, Bodnar RJ (1991) Can economic porphyry copper mineralization be generated by typical calc-alkaline melt? J Geophys Res 96: 8118-8126

Čopjaková R, ŠKoda R, Vašinová Galiová M, NovÁK M (2013) Distributions of $\mathrm{Y}+\mathrm{REE}$ and Sc in tourmaline and their implications for the melt evolution; examples from NYF pegmatites of the Třebíč Pluton, Moldanubian Zone, Czech Republic. J Geosci 58: 113-131

Čopjaková R, ŠKoda R, Vašinová Galiová M, Novák M, CEMPÍREK J (2015) Scandium- and REE-rich tourmaline replaced by Sc-rich REE-bearing epidote-group mineral from the mixed (NYF + LCT) Kracovice pegmatite (Moldanubian Zone, Czech Republic). Amer Miner 100: 1434-1451

Dingwell DB, Pichavant M, Holtz F (1996) Experimental studies of boron in granitic melts. In: GREW ES, ANOVITZ LM (eds) Boron: Mineralogy, Petrology and Geochemistry. Reviews in Mineralogy and Geochemistry 33: 331-379

Dolníček Z, René M, Prochaska W, KováŘ M (2012) Fluid evolution of the Hub Stock, Horní Slavkov-Krásno Sn-W ore district, Bohemian Massif, Czech Republic. Miner Depos 47: 821-833

Dostal J, Chatterjee AK (2000) Contrasting behaviour of $\mathrm{Nb} / \mathrm{Ta}$ and $\mathrm{Zr} / \mathrm{Hf}$ ratios in a peraluminous granitic pluton (Nova Scotia, Canada). Chem Geol 163: 207-218

Duan ZH, Moller N, Weare JH (1992) An equation of state for the $\mathrm{CH}_{4}-\mathrm{CO}_{2}-\mathrm{H}_{2} \mathrm{O}$ system. II. Mixtures from 50 ${ }^{\circ} \mathrm{C}$ to $1000{ }^{\circ} \mathrm{C}$ and 0 to 1000 bar. Geochim Cosmochim Acta 56: 2619-2631

Dutrow BL, Henry DJ (2011) Tourmaline: a geologic DVD. Elements 7: 301-306
Filip J, Bosi F, Novák M, Skogby H, Tuček J, Čuda J, Wildner M (2012) Redox processes of iron in the tourmaline structure: example of the high-temperature treatment of $\mathrm{Fe}^{3+}$-rich schorl. Geochim Cosmochim Acta 86: 239-256

Finger F, Roberts MP, Haunschmid B, Schermaier A, SteyRER HP (1997) Variscan granitoids of Central Europe: their typology, potential sources and tectonothermal relations. Mineral Petrol 61: 67-96

Finger F, Gerdes A, Janoušek V, René M, Riegler G (2007) Resolving the Variscan evolution of the Moldanubian sector of the Bohemian Massif: the significance of the Bavarian and the Moravo-Moldanubian tectonometamorphic phases. J Geosci 52: 9-28

Gadas P, Novák M, StaněK J, Filip J, Vašinová Galiová M (2012) Compositional evolution of zoned tourmaline crystals from pockets in common pegmatites, the Moldanubian Zone, Czech Republic. Canad Mineral 50: 895-912

Gao LE, Zeng LS, Asimow PD (2017) Contrasting geochemical signatures of fluid-absent versus fluid-fluxed melting of muscovite in metasedimentary sources: the Himalayan leucogranites. Geology 45: 39-42

Grant JA (1986) The isocon diagram - a simple solution to Gresen's equation for metasomatic alteration. Econ Geol 81: 1976-1982

Greenfield JE, Clarke GL, Bland M, Clark DC (1996) In-situ migmatite and hybrid diatexite at Mt Stafford, central Australia. J Metamorph Geol 14: 413-426

Greenfield JE, Clarke GL, White RW (1998) A sequence of partial melting reactions at Mt Stafford, central Australia. J Metamorph Geol 16: 363-378

Henry DJ, Novák M, Hawthorne FC, Ertl A, Dutrow BL, Uher P, Pezzotta F (2011) Nomenclature of the tourmaline-supergroup minerals. Amer Miner 96: 895-913

Hoefs J, Emmermann R (1983) The oxygen isotope composition of Hercynian granites and pre-Hercynian gneisses from the Schwarzwald, SW Germany. Contrib Mineral Petrol 83: 320-329

Holtz F, Johannes W (1991) Effect of tourmaline on melt fraction and composition of first melts in quartzofeldspathic gneiss. Eur J Mineral 3: 527-536

Holub FV (1997) Ultrapotassic plutonic rocks of the durbachite series in the Bohemian Massif: petrology, geochemistry and petrogenetic interpretation. Sbor geol Věd, ložisk Geol Mineral 31: 5-26

Holub FV, Machart J, Mráz L (1981) Tourmaline nodules from the Eisgarn granite near Volary. Acta Univ Carol, Geol 1981: 363-377 (in Czech with English summary)

Holub FV, KlečKa M, MatěJKa D (1995) Igneous activity. In: Dallmeyer RD, Franke W, Weber K (eds) Pre-Permian Geology of Central and Eastern Europe. Springer, Berlin, pp 444-452 
Holub FV, Cocherie A, Rossi P (1997) Radiometric dating of granitic rocks from the Central Bohemian Plutonic Complex (Czech Republic): constrains on the chronology of thermal and tectonic events along the Moldanubian-Barrandian boundary. C R Acad Sci Paris Earth Planet Sci 325: 19-26

Houzar S, NovÁK M (2006) Clintonite-bearing assemblages in chondrodite marbles from the contact aureole of the Třebíč Pluton, Moldanubian Zone, Bohemian Massif. J Czech Geol Soc 51: 249-258

Huang WL, Wyllie PJ (1981) Phase relationships of Stype granite with $\mathrm{H}_{2} \mathrm{O}$ to 35 kbar: muscovite granite from Harney Peak, South Dakota. J Geophys Res 86: 10515-10529

IRBER W (1999) The lanthanide tetrad effect and its correlation with $\mathrm{K} / \mathrm{Rb}, \mathrm{Eu} / \mathrm{Eu}^{*}, \mathrm{Sr} / \mathrm{Eu}, \mathrm{Y} / \mathrm{Ho}$, and $\mathrm{Zr} / \mathrm{Hf}$ of evolving peraluminous granite suites. Geochim Cosmochim Acta 63: 489-508

INGER S, HARRIS N (1993) Geochemical constraints on leucogranite magmatism in the Langtang Valley, Nepal Himalaya. J Petrol 34: 345-368

JANOUŠEK V, HoluB FV (2007) The causal link between HPHT metamorphism and ultrapotassic magmatism in collisional orogens: case study from the Moldanubian Zone of the Bohemian Massif. Proc Geol Assoc 118: 75-86

JANOUŠEK V, FARROW CM, ERBAN V (2006) Interpretation of whole-rock geochemical data in igneous geochemistry: introducing Geochemical Data Toolkit (GCDkit). J Petrol 47: 1255-1259

Jiang SY, Yang JH, Novák M, Selway JB (2003) Chemical and boron isotopic compositions of tourmaline from the Lavičky leucogranite, Czech Republic. Geochem J 37: 545-556

Kotková J, Schaltegger U, Leichmann J (2010) Two types of ultrapotassic plutonic rocks in the Bohemian Massif - coeval intrusions at different crustal levels. Lithos 115: $163-176$

Kubiš M, Broska I (2005) Role of boron and fluorine in evolved granitic rock systems (on example Hnilec area, Western Carpathians). Geol Carpath 56: 193-204

KuBIŠ M, BRoskA I (2010) The granite system near Betliar village (Gemeric Superunit, Western Carpathians): evolution of a composite silicic reservoir. J Geosci 55: 131-148

Kusiak MA, Dunkley DJ, Suzuki K, Kachlík V, Kedzior A, LeKKi J, Opluštil S (2010) Chemical (non-isotopic) and isotopic dating of Phanerozoic zircon - a case study of durbachite from the Třebíč Pluton, Bohemian Massif. Gondwana Res 17: 153-161

Leichmann J, Gnojek I, Novák M, Sedlák J, Houzar S (2017) Durbachites from the eastern Moldanubicum (Bohemian Massif): erosional relics of large, flat tabular intrusions of ultrapotassic melts - geophysical and petrological record. Int J Earth Sci 106: 59-77

Lexa O, Schulmann K, Janoušek V, ŠTípská P, Guy A, RACEK M (2011) Heat sources and trigger mechanisms of exhumation of HP granulites in Variscan orogenic root. J Metamorph Geol 29: 79-102

LONDON D (1986) Formation of tourmaline-rich gem pockets in miarolitic pegmatites. Amer Miner 71: 396-405

LonDon D (1999) Stability of tourmaline in peraluminous granite systems; the boron cycle from anatexis to hydrothermal aureoles. Eur J Mineral 11: 253-262

London D (2008) Pegmatites. Canad Mineral, Special Publication 10: pp 1-368

LONDON D (2011) Experimental synthesis and stability of tourmaline: a historical overview. Canad Mineral 49: 117-136

London D, MANNING DAC (1995) Compositional variation and significance of tourmaline from southwest England. Econ Geol 90: 495-519

London D, Morgan GB VI, Wolf MB (1996) Boron in granitic rocks and their contact aureoles. In: GREw ES, Anovitz LM (eds) Boron: Mineralogy, Petrology and Geochemistry. Reviews in Mineralogy and Geochemistry 33: 299-330

LONGFELlow KM, Swanson S (2009) Euhedral and skeletal tourmaline in the Stone Mountain Granite, Georgia, USA. Canad Mineral 49: 341-357

Marschall HR, Jiang SY (2011) Tourmaline isotopes: no element left behind. Elements 7: 313-319

Marschall HR, Ludwig T (2006) Re-examination of the boron isotopic compositions of tourmaline from the Lavičky granite, Czech Republic, by secondary ion mass spectrometry: back to normal. Geochem J 40: 631-638

MaruéJol P, Cuney M, Turpin L (1990) Magmatic and hydrothermal REE fractionation in the Xihuashan granites (SE China). Contrib Mineral Petrol 104: 668-680

Míková J, NovÁk M, JANOUŠEk V (2010) Boron isotopes in tourmaline of dravite-schorl series from granitic pegmatites of the Moldanubian Zone, Czech Republic. Acta Mineral Petrogr, Abstr Volume 6: 475

Montel JM (1993) A model for monazite/melt equilibrium and application to the generation of granitic magmas. Chem Geol 110: 127-146

Morgan GB VI, London D (1999) Crystallization of the Little Three layered pegmatite-aplite dike, Ramona District, California. Contrib Mineral Petrol 136: 310-330

Nabelek PI, Whittington AG, Sirbescu MLC (2009) The role of $\mathrm{H}_{2} \mathrm{O}$ in rapid emplacement and crystallization of granite pegmatites: resolving the paradox of large crystals in highly undercooled melts. Contrib Mineral Petrol 160: 313-325

NĚMEC D (1975) Genesis of tourmaline spots in leucocratic granites. Neu Jb Mineral, Mh 7: 308-317

Neves LJPF (1997) Trace element content and partitioning between biotite and muscovite of granitic rocks; a study in the Viseu region (central Portugal). Eur J Mineral 9: 849-857 
NovÁK M, FiliP J (2010) Unusual (Na, Mg)-enriched beryl and its breakdown products (beryl II, bazzite, bavenite) from euxenite-type NYF pegmatite related to the orogenic ultrapotassic Třebíč Pluton, Czech Republic. Canad Mineral 48: 615-628

Novák M, Houzar S (1996) The HT/LP metamorphism of dolomite marbles in the eastern part of the Moldanubicum, a manifestation of heat flow related to the Třebíc durbachite massif. J Czech Geol Soc 41: 139-146

Novák M, Selway JB, Uher P (1997) Locality No. 6: Lavičky near Velké Meziříčí; quartz-tourmaline orbicules in leucocratic two-mica granite tourmaline in barren pegmatite and hydrothermal quartz-tourmaline veins. In: NovÁk M, SELway JB (eds) International Symposium Tourmaline 1997, Nové Město na Moravě, June 1997, Field Trip Guidebook. Moravian Museum, Brno, pp 77-84

Novák M, Selway JB, Černý P, Hawthorne FC (1999) Tourmaline of the elbaite-dravite series from an elbaitesubtype pegmatite at Bližná, southern Bohemia, Czech Republic. Eur J Mineral 11: 557-568

Novák M, Povondra P, Selway JB (2004) Schorl-oxyschorl to dravite-oxy-dravite tourmaline from granitic pegmatites; examples from the Moldanubicum, Czech Republic. Eur J Mineral 16: 323-333

Novák M, Š́oda R, Filip J, MAcek I, Vaculovič T (2011) Compositional trends in tourmaline from intragranitic NYF pegmatites of the Třebíč Pluton, Czech Republic: an electron microprobe, Mössbauer and LA-ICP-MS study. Canad Mineral 49: 359-380

Perugini D, Poli G (2007) Tourmaline nodules from Capo Bianco aplite (Elba Island, Italy): an example of diffusion limited aggregation growth in a magmatic system. Contrib Mineral Petrol 153: 493-508

Pesquera A, Torres-Ruiz J, García-Casco A, Gil-Crespo PG (2013) Evaluating the controls on tourmaline formation in granitic systems: a case study on peraluminous granites from the Central Iberian Zone (CIZ), Western Spain. J Petrol 54: 609-634

Pichavant M (1981) An experimental study of the effect of boron on a water-saturated haplogranite at 1 kbar vapor pressure. Contrib Mineral Petrol 76: 430-439

Pichavant M, Manning D (1984) Petrogenesis of tourmaline granites and topaz granites; the contribution of experimental data. Phys Earth Planet Inter 35: 31-50

Pichavant M, Valencia-Herrera J, Boulmier S, Briqueu L, Joron JL, Juteau M, Marin L, Michard A, Sheppard S, Treuil M, Vernet M (1987) The Macusani glasses, SE Peru: evidence of chemical fractionation in peraluminous magmas. In: Mysen BO (ed) Magmatic Processes: Physicochemical Principles. Geochemical Society, Special Publications 1: 359-373

Polya DA, Foxford KA, Stuart F, Boyce A, Fallick AE (2000) Evolution and paragenetic context of low $\delta \mathrm{D}$ hydrothermal fluids from the Panasqueira W-Sn deposit, Portugal: new evidence from microthermometric, stable isotope, noble gas and halogen analyses of primary fluid inclusions. Geochim Cosmochim Acta 64: 3357-3371

Pouchou JL, Pichoir F (1985) "PAP" procedure for improved quantitative microanalysis. Microbeam Anal 20: $104-105$

PoVONDRA P (1981) The crystal chemistry of tourmalines of the schorl-dravite series. Acta Univ Carol, Geol 1981: 223-264

Povondra P, Lang M, Pivec E, Ulrych J (1998) Tourmaline from the Prribyslavice peraluminous alkali-feldspar granite, Czech Republic. J Czech Geol Soc 43: 3-8

Richardson SW, Gilbe MC, BetL PM (1969) Experimental determination of kyanite-andalusite and andalusite-sillimanite equilibria: the aluminum silicate-triple point. Amer J Sci 267: 259-272

Roedder E (ed) (1984) Fluid Inclusions. Reviews in Mineralogy and Geochemistry 12: 1-644

RozendaAl A, BRuwer L (1995) Tourmaline nodules: indicators of hydrothermal alteration and $\mathrm{Sn}-\mathrm{Zn}-(\mathrm{W})$ mineralization in the Cape Granite Suite, South Africa. J Afr Earth Sci 21: 141-155

Scaillet B, Pichavant M, Roux J (1995) Experimental crystallization of leucogranite magmas. J Petrol 36: 663-705

Schatz OJ, Dolejš D, Stix J, Williams-Jones AE, Layne GD (2004) Partitioning of boron melt, brine and vapor in the system haplogranite- $\mathrm{H}_{2} \mathrm{O}-\mathrm{NaCl}$ at $800{ }^{\circ} \mathrm{C}$ and 100 MPa. Chem Geol 210: 135-147

Schulmann K, Konopásek J, Janoušek V, Lexa O, Lardeaux JM, Edel JB, ŠTíPSKÁ P, UlRich S (2009) An Andean type Palaeozoic convergence in the Bohemian Massif. C R Geosci 341: 266-286

Selverstone J, Hyatt J (2003) Chemical and physical responses to deformation in micaceous quartzites from the Tauern Window, Eastern Alps. J Metamorph Geol 21: $335-345$

ShePherd TJ, RANKIn AH, Alderton DHM (1985) A Practical Guide to Fluid Inclusion Studies. Blackie, Glasgow and London, pp 1-239

SinCLAIR WD, Richardson JM (1992) Quartz-tourmaline orbicules in the Seagull Batholith, Yukon Territory. Canad Mineral 30: 923-935

Spicer EM, Stevens G, Buick IS (2004) The low-pressure partial-melting behaviour of natural boron-bearing metapelites from the Mt. Stafford area, central Australia. Contrib Mineral Petrol 148: 160-179

Swanson SE, Fenn PM (1992) The effect of $\mathrm{F}$ and $\mathrm{Cl}$ on albite crystallization: a model for granitic pegmatites. Canad Mineral 30: 549-559

SyLVESTER PJ (1998) Post-collisional strongly peraluminous granites. Lithos 45: 29-44

Š́oda R, Novák M (2007) Y, REE, Nb, Ta, Ti-oxide $\left(\mathrm{AB}_{2} \mathrm{O}_{6}\right)$ minerals from REL-REE euxenite-subtype 
pegmatites of the Třebíč Pluton, Czech Republic; substitutions and fractionation trends. Lithos 95: 43-57

ŠKoda R, Novák M, Houzar S (2006) Granitic NYF pegmatites of the Třebíč Pluton. Acta Mus Moraviae, Sci geol 91: 129-176 (in Czech with English summary)

TaYlor SR, McLennan SM (1995) The geochemical evolution of the continental crust. Rev Geoph 33: 241-265

THOMAS AV, SpOOnER ETC (1988) Fluid inclusions in the system $\mathrm{H}_{2} \mathrm{O}-\mathrm{CH}_{4}-\mathrm{NaCl}-\mathrm{CO}_{2}$ from metasomatic tourmaline within the border unit of the Tanco zoned granitic pegmatite, S.E. Manitoba. Geochim Cosmochim Acta 52: 1065-1075

Thomas R, Webster JD (2000) Strong tin enrichment in a pegmatite-forming melt. Miner Depos 35: 570-582

ThOMAS R, Förster HJ, HeinRICH W (2003) The behaviour of boron in a peraluminous granite-pegmatite system and associated hydrothermal solutions: a melt and fluidinclusion study. Contrib Mineral Petrol 144: 457-472

Touret JLR, Smirnov SZ, Peretyazhko IS, Zagorsky VY, Thомas VG (2007) Magmatic/hydrothermal transition in tourmaline-bearing miarolitic pegmatites: hydrosaline fluids or silica gels? In: Martins T, VieIRA R (eds) Granitic Pegmatites: The State of the Art, 6-12 May 2007, Porto, book of abstracts. Memórias 8, Departamento de Geologia, Faculdade de Ciências da Universidade do Porto, Porto, pp 92-93

Trumbull RB, Krienitz, M-S, Gottesmann B, Wiedenbeck $M$ (2008) Chemical and boron-isotope variations in tourmalines from an S-type granite and its source rocks: the Erongo granite and tourmalinites in the Damara Belt, Namibia. Contrib Mineral Petrol 155: 1-18

Tuttle OF, Bowen NL (1958) Origin of Granite in the Light of Experimental Studies in the System $\mathrm{NaAlSi}_{3} \mathrm{O}_{8}-$ $\mathrm{KAlSi}_{3} \mathrm{O}_{8}-\mathrm{SiO}_{2}-\mathrm{H}_{2} \mathrm{O}$. Geological Society of America, Memoirs 74: 1-153

van Hinsberg VJ, Henry DJ, Dutrow BL (2011) Tourmaline as a petrologic forensic tool: a unique recorder of its geologic past. Elements 7: 327-332

VeKsLer IV (2004) Liquid immiscibility and its role at the magmatic-hydrothermal transition: a summary of experimental studies. Chem Geol 210: 7-31

VeKsLeR IV, THOMAS R (2002) An experimental study of B-, $\mathrm{P}$ - and F-rich synthetic granite pegmatite at 0.1 and 0.2 GPa. Contrib Mineral Petrol 143: 673-683

Versler IV, Thomas R, Schmidt C (2002) Experimental evidence of three coexisting immiscible fluids in synthetic granitic pegmatite. Amer Miner 87: 775-779

Vellmer C, Wedepohl KH (1994) Geochemical characterization and origin of granitoids from the South Bohemian
Batholith in Lower Austria. Contrib Mineral Petrol 118: 13-32

Villaseca GC, Barbero GLC (1994) Chemical variability of $\mathrm{Al}-\mathrm{Ti}-\mathrm{Fe}-\mathrm{Mg}$ minerals in peraluminous granitoid rocks from Central Spain. Eur J Mineral 6: 691-710

WATSON E, HARRISON T (1983) Zircon saturation revisited: temperature and composition effects in a variety of crustal magma types. Earth Planet Sci Lett 64: 295-304

Webber KL, Simmons WmB (2007) Crystallization dynamics. In: Martins T, Vieira R (eds) Granitic Pegmatites: The State of the Art, 6-12 May 2007, Porto, book of abstracts. Memórias 8, Departamento de Geologia, Faculdade de Ciências da Universidade do Porto, Porto, pp 17-19

Webber KL, Simmons WB, Falster AU, Foord EE (1999) Cooling rates and crystallization dynamics of shallow level pegmatite-aplite dikes, San Diego County, California. Amer Miner 84: 708-717

Wenzel T, Mertz DF, Oberhänsli R, Becker T, Renne PR (1997) Age, geodynamic setting, and mantle enrichment processes of a K-rich intrusion from the Meissen Massif (northern Bohemian Massif) and implications for related occurrences from the mid-European Hercynian. Geol Rundsch 86: 556-570

WhitNEy DL, EvAns BW (2010) Abbreviations for names of rock-forming minerals. Amer Miner 95: 185-187

Wolf MB, LoNDON D (1997) Boron in granitic magmas: stability of tourmaline in equilibrium with biotite and cordierite. Contrib Mineral Petrol 130: 12-30

ZACHǍ̌ A, NovÁK M (2013) Granitic NYF pegmatites in the Velké Meziříćí region, Třebíč Pluton, western Moravia (Czech Republic). Acta Mus Moraviae, Sci Geol 98: 83-100 (in Czech with English summary)

Žák J, Verner K, Janoušek V, Holub FV, Kachlík V, Finger F, Hajná J, Tomek F, Vondrovic L, Trubač J (2014) A plate-kinematic model for the assembly of the Bohemian Massif constrained by structural relationships around granitoid plutons. In: SCHULMANN K, Martínez Catalán JR, Lardeaux JM, Janoušek V, Oggiano G (eds) The Variscan Orogeny: Extent, Timescale and the Formation of the European Crust. Geological Society, London, Special Publications 405: pp 169-196

ZHANG Y, FRANTZ JD (1987) Determination of the homogenization temperatures and densities of supercritical fluids in the system $\mathrm{NaCl}-\mathrm{KCl}-\mathrm{CaCl}_{2}-\mathrm{H}_{2} \mathrm{O}$ using synthetic fluid inclusions. Chem Geol 64: 335-350 